CUADERNOS DE ESTUDIOS GALLEGOS, LXVIII

Núm. 134 (enero-diciembre 2021), págs. 267-306

ISSN: $0210-847 \mathrm{X}$

https://doi.org/10.3989/ceg.2021.134.09

\title{
EL ALTAR MAYOR DE LA CATEDRAL DE SANTIAGO EN TIEMPOS DEL \\ ARZOBISPO HERRERO ESGUEVA (1723-1727): EL GRABADO DEL PINTOR MIGUEL VARELA ADQUIRIDO POR UN PEREGRINO
}

\author{
Miguel TAín GuZMÁN \\ Universidad de Santiago de Compostela \\ ORCID iD: http://orcid.org/0000-0002-7745-6335
}

Copyright: (C) 2021 CSIC. La edición electrónica de esta revista se distribuye bajo los términos
de una licencia de uso y distribución Creative Commons Reconocimiento 4.0 Internacional
(CC BY 4.0).
Cómo citar/Citation: MiguEL TAín GuZMÁN, "El altar mayor de la catedral de Santiago en
tiempos del arzobispo Herrero Esgueva (1723-1727): el grabado del pintor Miguel Varela
adquirido por un peregrino", Cuadernos de Estudios Gallegos, 68, núm. 134 (2021), págs.
267-306, https://doi.org/10.3989/ceg.2021.134.09 


\section{EL ALTAR MAYOR DE LA CATEDRAL DE SANTIAGO EN TIEMPOS DEL ARZOBISPO HERRERO ESGUEVA (1723-1727): EL GRABADO DEL PINTOR MIGUEL VARELA ADQUIRIDO POR UN PEREGRINO}

\section{RESUMEN}

El peregrino francés Étienne Boret peregrinó a Compostela en 1749 y 1761. De su primera peregrinación se conserva su compostela, dos impresos sueltos con las listas de las reliquias de la catedral, así como un inédito y espléndido grabado de la capilla mayor dibujada por Miguel Varela. En este último se representa la escenografía barroca del recinto en tiempos del arzobispo Miguel Herrero Esgueva. Se trata del aparato construido entre las décadas de 1650 y 1670, siendo canónigo fabriquero José de Vega y Verdugo, para la presentación de la imagen medieval de Santiago in cathedra del altar mayor objeto del abrazo de los peregrinos; del Santiago Peregrino y los cuatro reyes españoles rindiéndole homenaje sobre el camarín; así como del Santiago Matamoros atacando cuatro sarracenos en el baldaquino. No obstante, el grabado documenta interesantes cambios posteriores, particularmente la platería añadida al altar, al camarín y a la estatua sedente del Apóstol, financiada por el arzobispo fray Antonio de Monroy (1685-1715) para enriquecer el escenario, siguiendo los postulados de la Contrarreforma.

PALABRAS ClAVE: Santiago de Compostela, Barroco, altar mayor, peregrinación.

\section{O ALTAR MAIOR DA CATEDRAL DE SANTIAGO EN TEMPOS DO ARCEBISPO HERRERO ESGUEVA (1723-1727): O GRAVADO DO PINTOR MIGUEL VARELA ADQUIRIDO POR UN PEREGRINO}

RESUMO

O peregrino francés Étienne Boret fixo dúas peregrinacións a Compostela a primeira en 1749 e a segunda 1761. Proba da primeira é a súa compostela, dous impresos soltos coas listas das reliquias da catedral, así como un gravado inédito e espléndido da capela maior debuxada por Miguel Varela. Neste último represéntase a escenografía barroca do recinto en tempos do arcebispo Miguel Herrero Esgueva, e inclue elementos como a mesa do altar; o camarín coa imaxe medieval de Santiago en cathedra obxecto da aperta dos peregrinos; o Santiago Peregrino e os catro reis españois rendéndolle homenaxe; así como o baldaquino co Santiago Matamoruos atacando a catro sarracenos. Trátase do aparello para a presentación das tres esculturas xacobeas construído entre os anos 1650 e 1670, sendo cóengo fabriqueiro José de Vega y Verdugo. Non obstante, o gravado tamén documenta cambios posteriores interesantes, en particular a prata engadida á mesa do altar, ao camarín e á estatua sedente do Apóstolo, financiada polo arcebispo fray Antonio de Monroy (1685-1715) para enriquecer o escenario, seguindo os postulados da Contrarreforma.

PALABRAS ClaVE: Santiago de Compostela, Barroco, altar maior, peregrinación.

\section{THE MAIN ALTAR OF THE CATHEDRAL OF SANTIAGO UNDER ARCHBISHOP HERRERO ESGUEVA (1723-1727): ENGRAVING BY THE PAINTER MIGUEL VARELA ACQUIRED BY A PILGRIM}

ABSTRACT

The French pilgrim Étienne Boret journeyed to Compostela in 1749 and again in 1761. Proof of the first pilgrimage is preserved among his personal effects with the compostela awarded to him, two loose printed sheets with lists of the different relics of the cathedral, as well as a splendid but unpublished engraving of the main chapel drawn by Miguel Varela. The latter depicts Baroque embellishments from the time of Archbishop Miguel Herrero Esgueva and shows the altar table; the camarín with the medieval image of Santiago in cathedra which pilgrims embraced; the representation of Santiago Peregrino and the four Spanish kings paying homage to him; as well as the baldachin with a Santiago Matamoros attacking four Saracens. Together they comprise the theatrical staging of St. James's representation to pilgrims with the three standard Jacobean images brought together between the 1650s and 1670s, when the canon José de Vega y Verdugo served as the cathedral's fabriquero. Nevertheless, the engraving records interesting subsequent changes, particularly the silver adornments added to the altar, to the camarin and to the medieval image of the Apostle. These enhancements were financed by Archbishop Friar Antonio de Monroy (1685-1715) to enrich the main ensemble, in agreement with the postulates of the Counter-Reformation.

KEY WORDS: Santiago de Compostela, Baroque, main altar, pilgrimage. 
Recibido/Received: 04/07/2020

Aceptado/Accepted: 20/09/2020

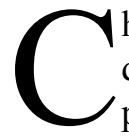

hristof Thoenes en su pionero estudio sobre los grabados de la basílica de San Pedro del Vaticano llamó la atención sobre el interés de la imagen para el estudio de la historia del monumento ${ }^{1}$. Tales palabras bien se pueden aplicar a la catedral de Santiago de Compostela que, con la iglesia de Roma, constituye un referente de la peregrinación europea desde la Edad Media tras el descubrimiento de la identificada como tumba del apóstol Santiago el Mayor en el siglo IX. Así lo refleja la declaración de la ciudad como Patrimonio de la Humanidad por la UNESCO en 1985; del Camino Francés como Primer Itinerario Cultural Europeo en 1987 y Patrimonio de la Humanidad en 1993; de los Caminos a Santiago de Compostela en Francia como Patrimonio de la Humanidad en 1998; y de los Caminos del Norte como Patrimonio de la Humanidad en 2015.

Como en el caso de la iglesia vaticana, se conoce la evolución del aspecto y distribución de la capilla mayor gracias a contadas pero valiosísimas imágenes en miniaturas, óleos y grabados donde aparece representada, realizadas por autores de diversa nacionalidad y cronología. La más antigua correspondería a la anónima del Tumbo B (ca. 1326), es decir después de la intervención del Maestro Mateo, donde aparece la actual imagen del Apóstol en cátedra, en su aspecto original, la mesa del altar cubierta por un rico paño y un baldaquino ${ }^{2}$. Le sigue en interés la conocida miniatura del Cartulario del Hospital de Saint-Jacques de Tournai (ca. 1489) donde figura el recinto tras las reformas de los arzobispos Alonso I y Alonso II de Fonseca, promotores de un nuevo baldaquino gótico y de la renovación del antiguo muro de la confessio, ahora parece que doble, aunque en la pintura solo se representa el externo hacia el presbiterio, con sus dos accesos en ambos extremos, para permitir a los peregrinos cumplir con los ritos del beso y el abrazo con la imagen apostólica ${ }^{3}$. Un grabado francés de 1648, de

\footnotetext{
${ }^{1}$ Christof Thoenes, La fabbrica di San Pietro nelle incisioni dal Cinquecento all'Ottocento, Milan, Il Polifilo, 2000.

2 Jesús Carro García, "La imagen sedente del apóstol en la Catedral de Santiago", Cuadernos de Estudios Gallegos, 15 (1950), págs. 43-44; Miguel Taín GuZMÁN, "L’altare dell’Apostolo e i riti jacopei nella cattedrale di Santiago de Compostela. Alcune immagini tra XIV e XIX secolo", Compostella. Rivista del Centro Italiano di Studi Compostellani, 34 (2013), págs. 12-13.

${ }^{3}$ Dominique Vanwijnsberghe, "Réalité et fiction chez le maitre du Livre d’Heures de Dresde. Le fron-
} 
justo antes la reestructuración barroca, contiene también la mesa del altar con la estatua del Apóstol, el circuito de los peregrinos para acceder a la imagen y la corona colgada sobre la cabeza del santo, objeto de la popular ceremonia de la coronatio peregrinorum citada durante siglos en la literatura de viajes ${ }^{4}$. Por fin, otro grabado de 1717, basado en un dibujo de muchos años antes, testimonia la nueva escenografía barroca después de las reformas emprendidas por el canónigo fabriquero José de Vega y Verdugo y los maestros de obras catedralicios Francisco de Antas y Domingo de Andrade entre las décadas de 1650 y 1670. $\mathrm{Su}$ origen cabría ligarlo a las celebraciones del año santo de esa fecha y a la necesidad de ofrecer a los peregrinos un recuerdo devocional de su peregrinación. Está firmado por el autor del dibujo, el pintor madrileño Juan Delgado, y por su impresor, el francés Gaspar Duchange, que lo publicó en sus talleres de París 5 .

A una desconocida representación de la capilla mayor realizada en tiempos del arzobispo Miguel Herrero Esgueva (1723-1727), muchos años después de haberse terminado la actual maquinaria barroca del recinto, se dedica este estudio, y permite completar el repertorio diacrónico de imágenes que documentan su historia, considerada capilla real en la época.

\section{LA PEREGRINACIÓN DE ETIENNE BORET EN 1749}

En los Archivos Departamentales de la Dordogne, en Francia, la archivera Bernard Reviriego ha localizado en el dossier A.D. 24, J 2041 la documentación de las diversas peregrinaciones del devoto Étienne Boret en el siglo XVIII, un personaje originario de Soumensac, en Lot-et-Garonne, del que apenas se tienen datos $^{6}$. La misma informa que peregrinó dos veces a Santiago de Compostela (en 1749 y 1761) y tres a Roma (en 1750, 1754 y 1769), así como que visitó un gran número de santuarios en Francia, Italia y España, como por ejemplo Mont

tispiece du Cartulaire de l'Hôpital Saint-Jacques de Tournai (Tournai, Bibliothèque de la Ville, Ms. 27)", Als ich can, Liber Amicorum in Memory of Professor Dr. Maurits Smeyers, Corpus of Illuminated Manuscripts, vol. 2, Leuven, Peeters, 2002, págs. 1509-1546; TAín GuZMÁN, “L’altare dell'Apostolo...”, págs. 15-17.

${ }^{4}$ Humbert JACOMET, "L'image de la majesté de Saint Jacques en France et sa relation à Compostelle. Etude iconographique", Actas del Congreso de Estudios Xacobeos, Santiago, Xunta de Galicia, 1995, pág. 460 y fig.13; Robert PlöTz, "Santiago de Compostela en la literatura odepórica", Santiago de Compostela: ciudad y peregrino, Actas del V Congreso Internacional de Estudios Xacobeos, Santiago, Xunta de Galicia, 2000, pág. 71; TAín GuZMÁn, "L’altare dell’Apostolo...”, págs. 17-18.

5 Miguel TAín GuZMÁn, "Il ritratto dell'altare maggiore della cattedrale di Santiago de Compostela del pittore Juan Delgado (1717)", Compostella. Rivista del Centro Italiano di Studi Compostellani, 38 (2017), págs. 47-54.

6 Bernard Reviriego, "Sur les traces des pèlerins", Mémoire de la Dordogne, Revue des Archives Départementales de la Dordogne, 3 (1993), págs. 11-12. Agradezco a la autora la noticia de la existencia de la documentación analizada en este estudio. 
Saint-Michel (en 1753), la basílica de La Daurade en Toulouse (en 1755), la basílica de Saint-Seurin de Burdeos (en 1767), el santuario de la Santa Casa de Loreto (en 1769), el santuario de Santa Maria della Vita en Bolonia (en 1769) o la iglesia de Saint-Sernin en Toulouse (en 1769), manifestando un gran interés por las reliquias y las imágenes devocionales. Los salvoconductos de paso y los certificados de buena salud necesarios para sus viajes, así como las indulgencias, grabados religiosos, oraciones, certificados de confesión, etc., adquiridos en sus diversos destinos, informan de sus desplazamientos y su cronología. También que fueron transportados con cuidado por Boret y luego guardados y archivados en su domicilio durante años, con la intención de mantener el recuerdo de las peregrinaciones que llevó a cabo a lo largo de su vida.

Como ya se ha dicho, sus dos romerías a Compostela tuvieron lugar en 1749 y 1761, ninguna de las dos ocasiones años santos, aunque la segunda se debe a la obligación de cumplir un voto (pour accomplir un voeu), visitando Madrid, Logroño, Burgos, León, la Cruz de los Ángeles en la catedral de Oviedo y el santuario de Nuestra Señora de Begoña en Bilbao. Ambas testimonian la vigencia de la peregrinación jacobea en Europa en los siglos de la Edad Moderna, particularmente entre las clases sociales más populares, y sobre todo entre italianos y franceses ${ }^{7}$. Prueba de la primera peregrinación, cuando contaba con 23 años, se conservan la compostela expedida en la catedral (Fig. 1), un impreso suelto con la lista de las reliquias catedralicias (Fig. 2), otro con las reliquias donadas por Alfonso III de Asturias el Magno (Fig. 3) y el grabado de la capilla mayor en tiempos del arzobispo Herrero Esgueva que luego analizaremos (Fig. 4). Los cuatro documentos ilustran tanto sobre la capacidad económica de Boret para adquirirlos como sobre la intensidad devocional jacobea de su propietario, común en el ambiente contrarreformista europeo ${ }^{8}$.

El certificado de la peregrinación y comunión hubo de adquirirlo, previo pago, en la capilla del Rey de Francia de la catedral ${ }^{9}$, después de oír misa en ella

\footnotetext{
7 Antonio López Ferreiro, Historia de la Santa A.M. Iglesia de Santiago de Compostela, vol. 9, Santiago, Seminario Conciliar Central, 1908, págs. 289-301 y apénd. doc. 29. Al respecto véase también Domingo Luis GonZÁLEZ LOPO, "Los avatares de la peregrinación jacobea en el Renacimiento y el Barroco”, en Miguel Romaní Martínez y María Ángeles Novoa Gómez (eds.), Homenaje a José García Oro, Santiago, Universidade de Santiago de Compostela, 2002, págs. 171-192.

${ }^{8}$ Ronnie Po-Chia Hsia, El mundo de la renovación católica, 1540-1770, Madrid, Akal, 2010.

9 En ella también lo adquieren los peregrinos italianos Gian Lorenzo Buonafede Vanti en 1717 (cfr. Gian Lorenzo Buonafede VAnti, Viaggio occidentale a S. Giacomo di Galizia, Nostra Signora della Barca e Finis Terrae (1717-18), Guido Tamburlini (ed.), Trieste, Università di Trieste, 2004, pág. 83) y Giacomo Antonio Naia en 1718 sin indicar su precio (cfr. Carmen Pugliese, Viaje a Santiago de Compostela di Giacomo Antonio Naia (1717-1719), Pomigliano d'Arco, Edizioni Compostellane, 2012, pág. 243). Guillaume Manier abona dos sueldos por él en 1726, transcribiendo su texto de contenido similar al certificado de Boret (cfr. José García Mercadal, Viajes de extranjeros por España y Portugal. Vol. 3: Siglo XVIII, Madrid, Aguilar, 1962, págs. 360-361).
} 


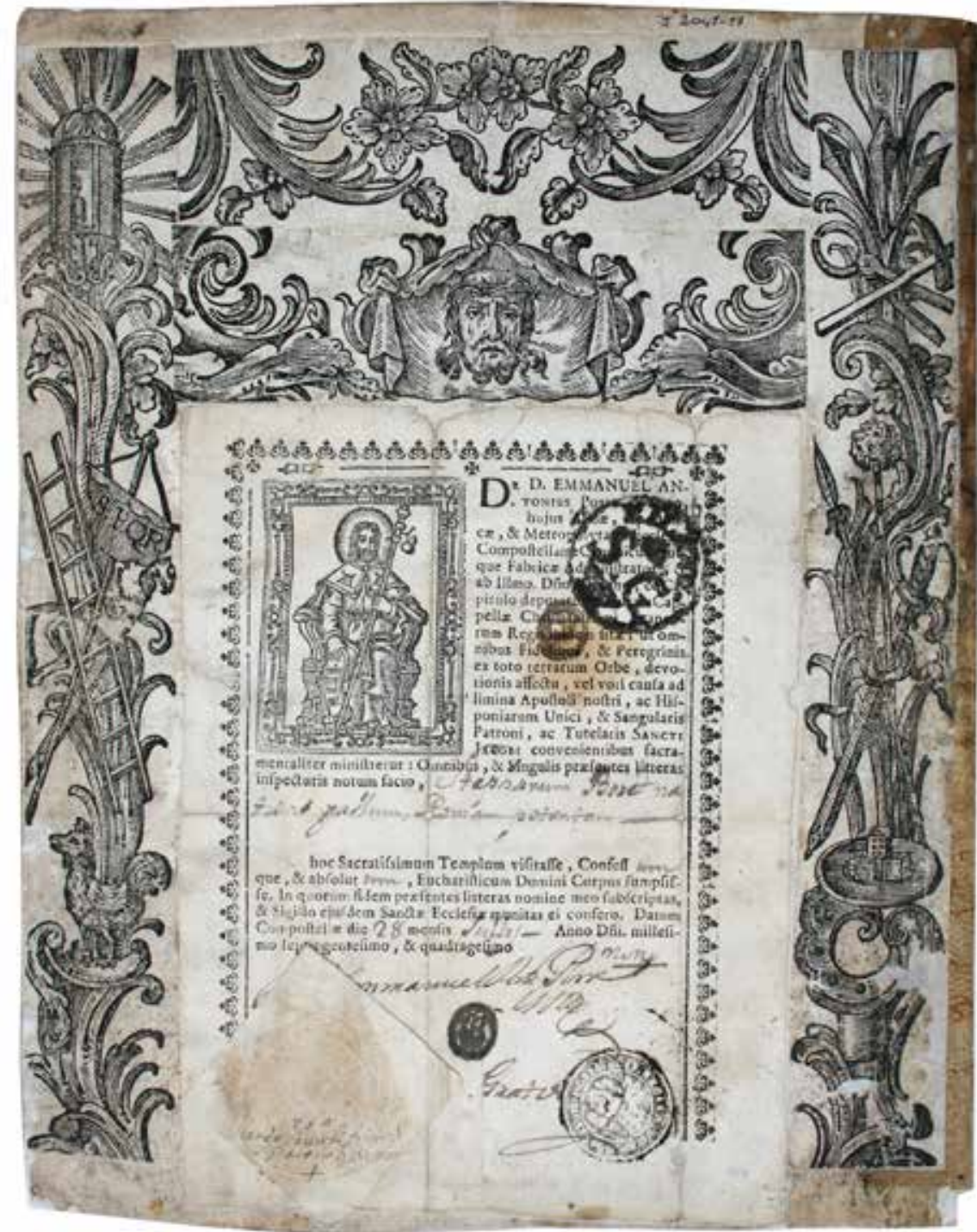

Fig. 1. Compostela que certifica la peregrinación de Etienne Boret en 1749; A.D. 24, J 2041-17; foto $(\mathcal{C}$ Archives Départementales de la Dordogne. 
a primera hora de la mañana y recibir la eucaristía ${ }^{10}$ (Fig. 1). Se trata de una de las muchas patentes impresas por la Fábrica con una xilografía del apóstol Santiago en cátedra vestido con las insignias de peregrino, es decir como la imagen venerada en el altar mayor ${ }^{11}$. Está firmada por el canónigo Manuel Antonio Pose y Soto, fabriquero de la basílica, administrador de la citada capilla y responsable de expedir el documento ${ }^{12}$. Su fecha, el 28 de julio, apuntaría al interés de Boret por hacer coincidir su llegada con las fiestas del apóstol. Igualmente, la indicación manuscrita Stephanum Boret natione gallum, Romam petentem informa que la peregrinación no terminaba en el santuario jacobeo, sino que seguía hacia Roma, a donde llegaría al año siguiente, es decir en pleno año jubilar romano. Así, la compostela le sirvió como credencial durante su posterior peregrinación romana y después en el regreso a su domicilio pues está documentado que algunas instituciones la exigían para albergar a los peregrinos. Es el caso de la Opera di San Jacopo en Pistoia que pidió en 1740 un ejemplar al cabildo compostelano para cotejarlo con los que presentaban los peregrinos que solicitaban hospedaje y limosna en sus instalaciones y, por consiguiente, poder distinguir los verdaderos de los falsos. La misma se conserva en el Archivo di Stato de Pistoia adjunta al libro de registro de entrada en la Opera, con la indicación manuscrita en español del lugar donde debía ir indicado el nombre, apellidos y la nacionalidad del peregrino, así como información sobre quien daba fe de la peregrinación en la catedral gallega y sobre el sello capitular de uso obligatorio que, en seco y con un Santiago Matamoros, se halla en un papel pegado en el ángulo inferior izquierdo $^{13}$. Lo interesante es que se trata del mismo impreso y sello que portaba Boret en su viaje, que además cuenta con las huellas de las instituciones que le asistieron durante el mismo: me refiero a una nota manuscrita a tinta y en italiano donde se lee 1750, Mateo Savioli, Prior di S. Giacomo di Rimini y cuatro sellos estampados a tinta: uno presenta la cruz de Calatrava y una inscripción en la que se llega a leer con claridad SIGIL(LUM) HOSPITALIS REGIS; otro, las ini-

\footnotetext{
${ }^{10}$ En ella comulga Manier en 1726 (cfr. García Mercadal, Viajes de extranjeros..., vol. 3, pág. 360) y el peregrino del Theatro Moral de Mendoza de los Ríos en 1731 (cfr. Pablo Mendoza de Los Ríos, Theatro moral y político de la noble academia compostelana, Santiago, [s. n.], 1731, pág. 77). El nombre de la capilla se debe a los donativos de Carlos V Le Sage, Luis XI o Francisco II para que tres capellanes dijesen misa en ella diariamente; cfr. LóPez Ferreiro, Historia de la Santa A.M. Iglesia de Santiago..., vol. 6, págs. 210-211; vol. 7, pág. 418; y vol. 8, págs. 440-441.

11 Yolanda Barriocanal LóPeZ, El grabado compostelano del siglo XVIII, A Coruña, Fundación Pedro Barrié de la Maza, 1996, págs. 68-72.

12 Véanse diferentes noticias sobre este prebendado en el volumen 10 de LóPEZ FERrEIRo, Historia de la Santa A.M. Iglesia de Santiago..., págs. 41, 91-92, 122 y 234, y apénd. doc. 16, pág. 80.

13 Véase reproducción del documento en Lucia GAI, "Certificado de peregrinación a Santiago (Compostela)", en Serafín Moralejo (comis.), Santiago, Camino de Europa. Culto y Cultura en la Peregrinación a Compostela, Santiago de Compostela, Fundación Caja Madrid; Xunta de Galicia; Arzobispado de Santiago de Compostela, 1993, págs. 353-354.
} 


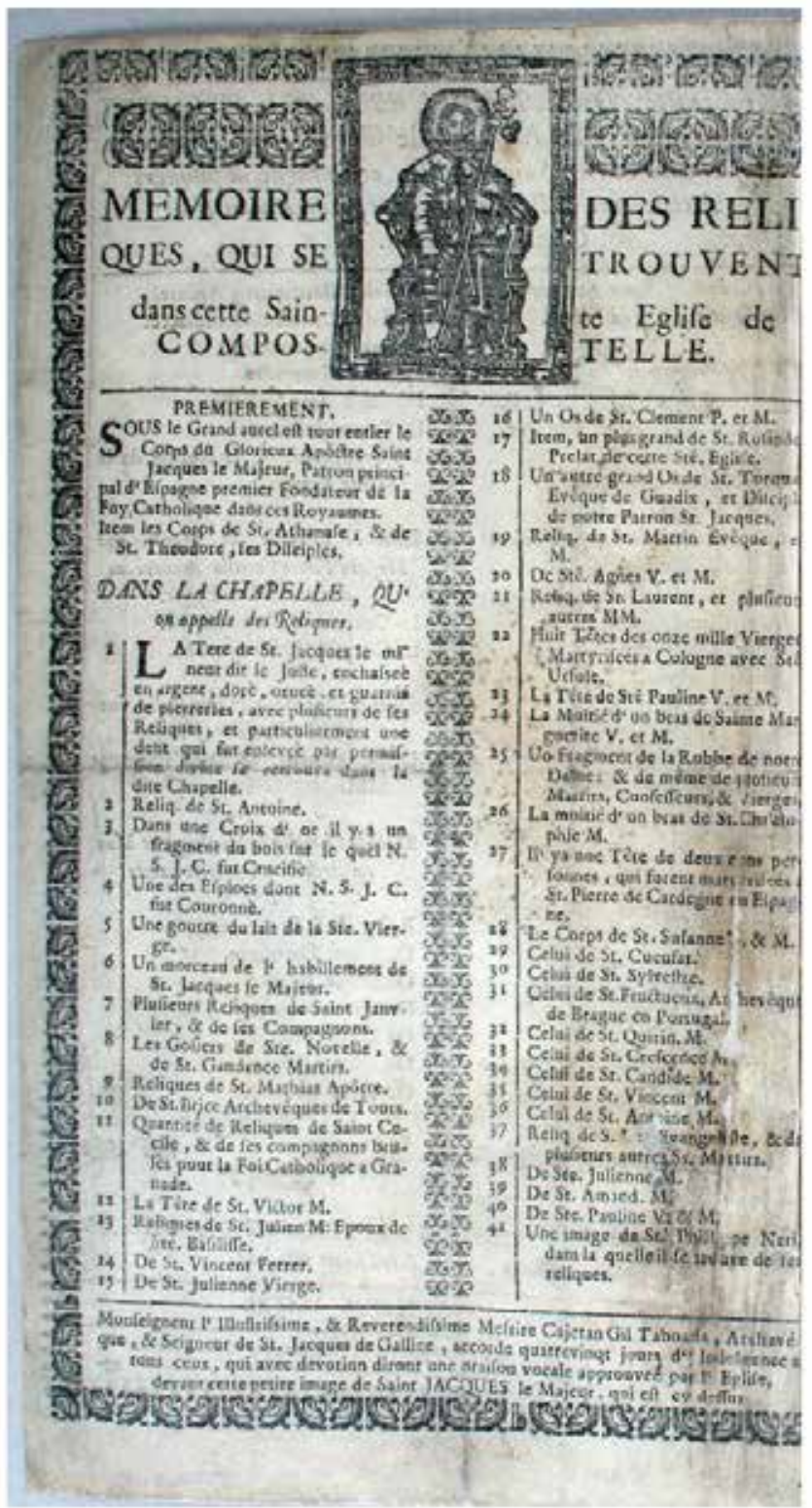

Fig. 2. Memoire des reliques qui se trouvent dans cette Sainte Eglise de Compostelle; A.D. 24, J 2041 - 18 v. ; foto $\odot$ Archives Départementales de la Dordogne. 
ciales SG que, como el anterior, no consigo identificar; y los dos restantes, con motivos borrosos, pequeños y difíciles de adjudicar. El documento presenta las dobleces, roturas y deterioro propias de su traslado en tan largo viaje y explica porque a posteriori se pegó a un papel mayor y se dignificó con el adorno de una orla estampada y recortada.

Los impresos con los listados de las reliquias de la catedral y de aquellas supuestamente donadas por Alfonso III de Asturias, ambos en lengua francesa ${ }^{14}$, habrían sido adquiridos a los dos reliquiarios encargados de la custodia de la lipsanoteca de la capilla de las Reliquias ${ }^{15}$ o bien al lenguajero políglota encargado por el cabildo de explicar la colección a los peregrinos en diferentes lenguas ${ }^{16}$ (Figs. 2 y 3). A este último debe de referirse el peregrino napolitano Nicola Albani cuando visita la capilla en 1743 al escribir que

les va enseñando y les hace ver con detalle cada una de las reliquias, y se las hace besar casi todas, y tocar también las coronas ${ }^{17}$ $u$ otras devociones que los peregrinos traen, y con gran minuciosidad les hace comprender esto y aquello, y aquella tal cabeza, y esta tal reliquia, y además les dan un papel impreso con todas las reliquias que hay alli, en alusión a nuestros dos papeles, que también había que pagar ${ }^{18}$.

El primero se titula Memoire des reliques qui se trouvent dans cette Sainte Eglise de Compostelle y cita las reliquias del Apóstol y sus discípulos, Teodoro y Atanasio, bajo el altar mayor, así como el elenco de las exhibidas en el retablo

\footnotetext{
14 Barriocanal LóPez, El grabado compostelano..., pág. 68.

15 Constituciones establecidas por el illustrísimo i reverendísimo Señor Don Francisco Blanco, arzobispo de Santiago, Santiago, Ignacio Aguayo, 1781 (reimpresión), págs. 27-30.

${ }^{16} \mathrm{Al}$ menos en el siglo XVII era así con Crispín de Evelino; cfr. Miguel TAín GuZMán, La ciudad de Santiago de Compostela según los hermanos Juan y Pedro Fernández de Boán (ca. 1633-1646), Santiago, Teófilo Edicións; Consorcio de Santiago, 2019, pág. 72. A cómo habían de ser sus explicaciones se dedica el punto 4 de la constitución capitular 18; cfr. Constituciones..., pág. 29.

17 El término "corone" del original está mal traducido por "coronas" significando en realidad "rosarios" aludiendo Albani a la costumbre de los peregrinos de tocar con estos las reliquias para impregnarlos con las cualidades talismáticas, profilácticas y taumatúrgicas de aquellas. Al respecto véase David FREEDBERG, El poder de las imágenes. Estudios sobre la historia y la teoría de la respuesta, Madrid, Cátedra, 1992, págs. 159-167.

18 Nicola Albani, Viaje de Nápoles a Santiago de Galicia, transcripción y traducción por Isabel González, Madrid, Edilán; Consorcio de Santiago, 1993, pág. 222; transcripción original en italiano en pág. 90. El peregrino Paolo Bacci también consigue el impreso en el mismo lugar en 1764; cfr. Giovanna ScALIA Rössler, "La Galizia nella relazione inédita di Paolo Bacci", en Paolo G. Caucci von Saucken (ed.), I testi italiani del viaggio e pellegrinaggio a Santiago de Compostela e diorama sulla Galizia, Perugia, Università degli Studi di Perugia, 1983, págs. 145-146. Naia en 1718 es quien afirma que hay que pagarlo; cfr. Pugliese, Viaje a Santiago..., pág. 243.
} 


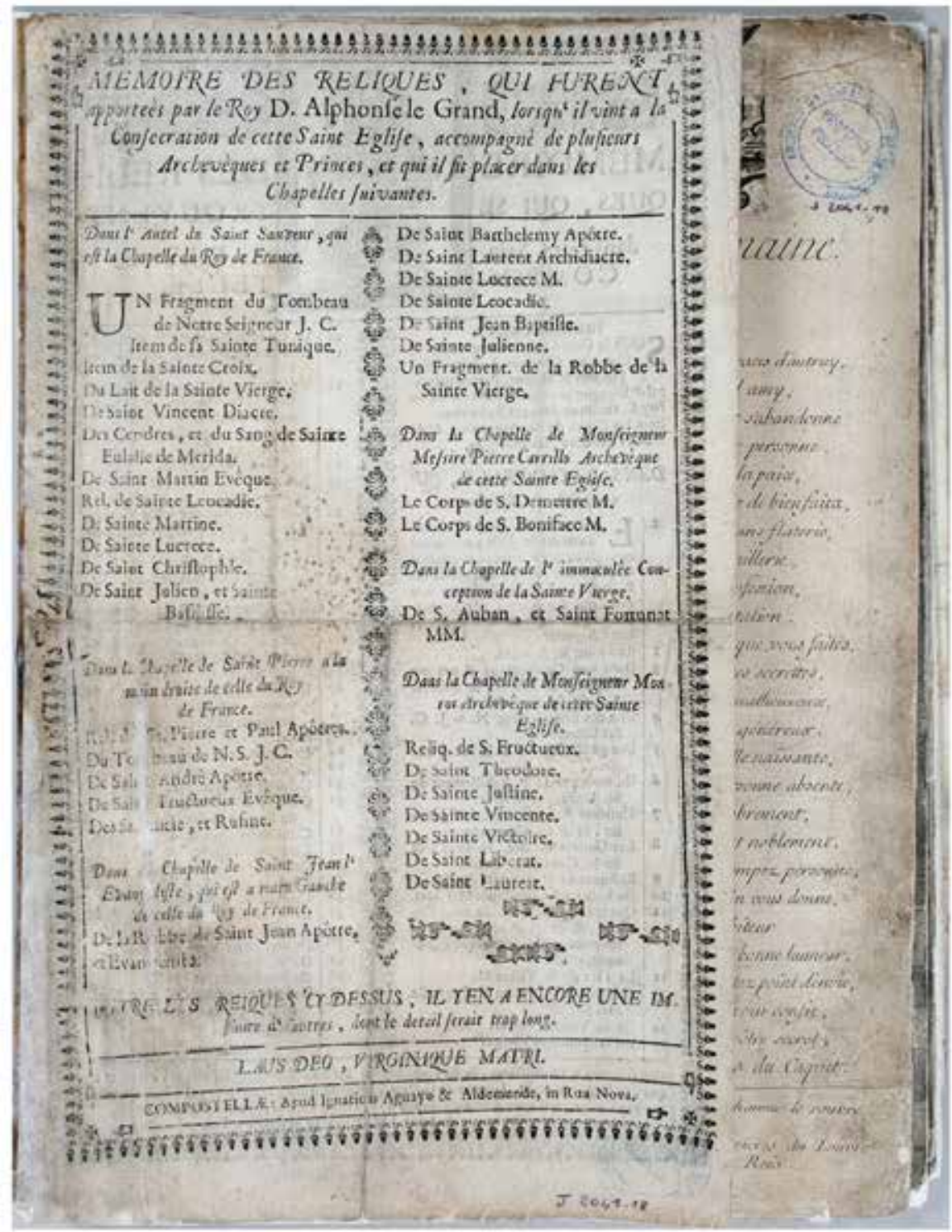

Fig. 3. Memoire des reliques qui furent apporteès par le Roy D. Alphonse le Grand lorsqu'il vint a la Consecration de cette Saint Eglise, accompagnè de plusieurs Archevèques et Princes, et qui il fit placer dans les Chapelles suivantes; A.D. 24, J 2041-18; foto (C) Archives Départementales de la Dordogne. 
de Bernardo Cabrera de 1625 en dicha capilla, destruido en el incendio de 1921, pero del que quedan algunos restos e imágenes ${ }^{19}$. Buena parte de las reliquias enumeradas parece que no se conservan, acaso destruidas también por el fuego, aunque sí algunas relevantes como el cráneo de Santiago Alfeo ${ }^{20}$. El impreso presenta el mismo grabado de Santiago sedente que contiene la compostela ya vista, pero aquí con la indicación expresa de que el arzobispo Cayetano Gil Taboada (1745-1751) concedía ochenta días de indulgencia a quien por devoción rezase a esta imagen una oración vocal aprobada por la Iglesia, incentivo claro para la compra del documento.

El segundo lleva el encabezamiento de Memoire des reliques qui furent apporteès par le roy D. Alphonse le Grand lorqu'il vint a la consecration de cette Saint Eglise, accompagnè de plusieurs archevèques et princes et qui il fit placer dans les chapelles suivantes, en referencia a las reliquias de las capillas del Rey de Francia, San Pedro, San Juan Evangelista, Santo Cristo de Burgos, Concepción y el arzobispo Monroy, terminando con la afirmación de que aún había muchas más, creídas donadas por Alfonso III de Asturias. Como en el caso anterior, parece que muchas de ellas hoy han desaparecido ${ }^{21}$. El impreso informa que fue estampado en la Rúa Nova por Ignacio Aguayo y Aldemunde (1753-1819), impresor del arzobispo y el cabildo, posiblemente el más importante de Galicia en su tiempo, con una abundantísima producción identificada, cuantificada en unos cuatrocientos cincuenta impresos, la mayoría menores ${ }^{22}$.

\section{CronologíA, AUTORÍA Y ORIGEN DEL GRABADO}

Como ya se ha dicho, entre los documentos localizados se halla un grabado de la capilla mayor de la catedral de Santiago, impreso entre 1723 y 1727 sobre un papel de 295 x $390 \mathrm{~mm}^{23}$, es decir durante el corto gobierno de la sede episco-

\footnotetext{
19 Alejandro Barral Iglesias, "El museo y el tesoro”, en Xosé Manuel García Iglesias (dir.), Santiago de Compostela, Laracha, Xuntanza Editorial, 1993 (Patrimonio Histórico Gallego I, Ciudades 2), págs. 502-503.

${ }^{20}$ Sobre algunas de las reliquias y sus relicarios llegados hasta nuestros días véanse Alejandro BARRAL IgLESIAS, "Reliquias y relicarios en la archidiócesis de Santiago", en José Manuel García Iglesias (comis.), En olor de santidad. Relicarios de Galicia, Santiago de Compostela, Xunta de Galicia, 2004, págs. 315-318; Ramón YzQuierdo Peiró, Los tesoros de la catedral de Santiago, Santiago de Compostela, Teófilo Edicións; Fundación Catedral de Santiago, 2018, págs. 339-370.

${ }^{21}$ Falta un estudio crítico sobre este tema.

${ }^{22}$ Xosé Ramón Barreiro Fernández, "Impresores galegos: Ignacio Aguayo y Aldemunde (17541819)”, Grial, vol. 21, núm. 82 (out.-dec. 1983), págs. 410-422; Antonio OdRIOzola y Xosé Ramón BARreiro, Historia de la imprenta en Galicia, La Coruña, Biblioteca Gallega, 1992, págs. 176-180; José Ignacio CABAno VÁzQuez (ed.), A imprenta en Galicia: Século XIX, Santiago de Compostela, Xunta de Galicia, 2002, 2 vols.

${ }^{23}$ Datos facilitados por el archivo.
} 
pal por Herrero Esgueva ${ }^{24}$ (Fig. 4). Su escudo consta duplicado en la representación: una panela sostenida por dos manos y, en el jefe, salientes, una espiga y un racimo de uvas; bordura con el lema DEO COR ET OMNIA (A Dios el corazón y todas las cosas). Las armas se disponen sobre un óvalo con cartela, con la cruz potenzada -como alumno del Colegio de Oviedo, en Salamanca- y la cruz de doble brazo acolada. Al timbre, capelo y borlas episcopales ${ }^{25}$. El mismo blasón aparece en el diploma de su toma de posesión de la sede episcopal, conservado en el archivo de la catedral ${ }^{26}$, así como en el ático del retablo de San Miguel de la iglesia parroquial de Santa Águeda en Sotillo de la Ribera, Burgos, financiado por el prelado por ser su villa natal; en una capa pluvial que regala a la parroquia por la misma razón; así como en su retrato, siempre en la referida iglesia, de 1727 y de autoría anónima ${ }^{27}$.

La obra aparece firmada por Bernabé de Quintáns (Suntib. Bernaba Quintans) y el pintor Miguel Varela (Michael Varela scul. comp.). Del primero solo se sabe que se imprime a su costa el libro del franciscano compostelano fray Francisco Villanueva y Sirguero titulado Miscellaneo sacro: contiene cinco tratados, los tres de oración, uno de la confesión, y otro de la Vía Sacra, con varios remedios para todos los vicios, y una devoción a Nuestra Señora y letanía..., al parecer tanto en Barcelona en 1722 como en Santiago en la imprenta de Antonio de Aldemunde en el mismo año ${ }^{28}$. Se trataría de un editor y librero con tienda en su casa de la Plaza del Campo en Santiago, actual Plaza de Cervantes. De Varela sólo sabemos que en 1743 cobraba del cabildo catedralicio su trabajo por pintar, dorar y estofar el arca de los ornatos de la coronación de Carlos III; y en 1751 por "componer" con pintura la Puerta Santa ${ }^{29}$. Sospecho que fue impresa en el contexto de los preparativos del Año Santo de 1728 para su distribución entre los peregrinos como recuerdo devocional: Herrero Esgueva murió inesperadamente

\footnotetext{
${ }^{24}$ Sobre su arzobispado véanse López Ferreiro, Historia de la Santa A. M. Iglesia de Santiago..., vol. 10, págs. 23-25; Manuel R. PAzos, El Episcopado gallego a la luz de documentos romanos, vol. 1, Madrid, Instituto Jerónimo Zurita, 1946, págs. 251-252.

${ }_{25}$ Agradezco a Eduardo Pardo de Guevara la lectura de la heráldica del prelado.

${ }^{26}$ Archivo de la Catedral de Santiago (en adelante ACS), IG 189, Jura y posesión de arzobispos, doc. 11 .

${ }^{27}$ Miguel Cortés Arrese, "Retrato de don Miguel Herrero y Esgueva, obispo de Osma", La Ciudad de Seis Pisos. Las Edades del Hombre, [catálogo de la exposición organizada por la Fundación Las Edades del Hombre en la catedral de El Burgo de Osma (Soria) en el año 1997], Valladolid, Fundación Las Edades del Hombre, 1997, págs. 350-351.

${ }^{28}$ Antonio González Polvillo, Análisis y repertorio de los tratados y manuales para la confesión en el mundo hispánico (ss. XV-XVIII), Huelva, Universidad de Huelva, 2009, pág. 336.

${ }_{29}$ Manuel MurguíA, El arte en Santiago durante el siglo XVIII y noticia de los artistas que florecieron en dicha ciudad y centuria, Madrid, Ricardo Fe, 1884, pág. 232; José CousElo BouZAs, Galicia Artística en el siglo XVIII y primer tercio del siglo XIX, Compostela, Imprenta del Seminario, 1932, pág. 642; Benedicto José QuiJada MorandeIRA, Las obras en la Catedral de Santiago desde 1751 a 1800 . Aportación documental, A Coruña, Diputación Provincial, 1997, págs. 6-7.
} 


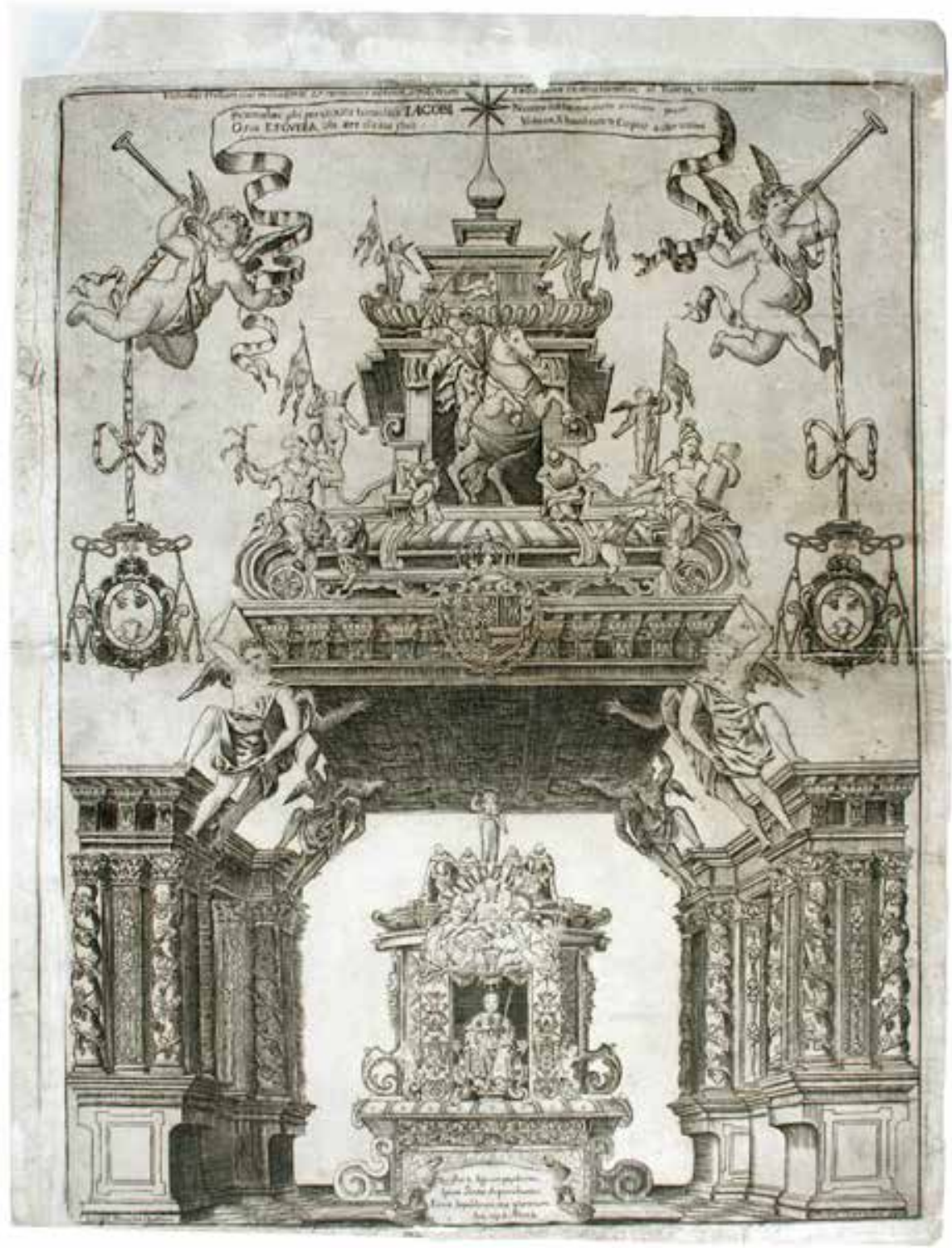

Fig. 4. Miguel Varela: el altar mayor de la catedral de Santiago de Compostela, grabado, 17231727; A.D. 24, J 2041-02; foto (C) Archives Départementales de la Dordogne. 
un 27 de julio de 1727 durante una visita pastoral a Pontedeume. Al respecto, David Freedberg explica que estas reproducciones eran comúnmente adquiridas por los peregrinos para llevar a casa como recuerdo del viaje. También para que le proporcionasen auxilio y consuelo en su vida diaria pues se esperaba que poseyeran la gracia de los originales, llegando a ser usadas como estampas de oración $^{30}$. De ahí que se le añadan lemas que garanticen la correcta identificación y alienten la devoción pese a la lejanía del original ${ }^{31}$. En el grabado compostelano hay tres textos de este tipo. Uno muy apretado a modo de encabezamiento: Vidimus stellam eius in Occidente, et venimus adorare sepulchrum, Stella Iacob contra Hereticos et Turcas ne moveare (Vimos una estrella en el oeste, venimos a adorar la tumba. Estrella de Jacobo contra heréticos y turcos, que nunca sea cambiada) en referencia al astro que remata el baldaquino catedralicio. Otro en una cartela textil sostenida por dos ángeles trompeteros, ambos con las mejillas hinchadas por la acción de soplar, el de la izquierda en actitud de volar mirando hacia siniestra y el de la derecha en acción de marcha caminando hacia la diestra. En ella se lee, en la columna de la izquierda: Piramis haec ubi pervivunt tumulata IACOBI, Ossa ESGUEBA tibi aere dicata fluit (Esta pirámide en bronce surge donde se hallan de forma perpetua los huesos apilados de Jacobo, te lo dedica Esgueba) en referencia a la ubicación del baldaquino sobre la tumba del Apóstol. Y en la de la derecha: Nomine sub tanto cunctis sic visere prestet, Umbram si haud cuncti Corpus adire valent (Bajo nombre tan magno ofrece a todos visitar no solo su espíritu sino todo el cuerpo) en referencia a la presencia apostólica en las reliquias enterradas en la catedral. Por fin, delante del frente del altar, se lee en otro pergamino: Qui stat in Signum populorum, Ipsum Gentes deprecabuntur, Et erit Sepulchrum eius gloriosum, Isa[ías], Cap. 11, Num. 10 (El que aparece como estandarte ante las gentes, a él acudirán los pueblos y su tumba será gloriosa) en referencia al Santiago caballero con pendón triunfal en la mano que surge del baldaquino. Los músicos alados no solo sostienen la cartela de este texto, sino también sendas cintas verticales, con lazo decorativo, de las que cuelgan los dos citados escudos del arzobispo, una composición que remite a los recursos propios del arte efímero del barroco ${ }^{32}$.

\footnotetext{
${ }^{30} \mathrm{Al}$ respecto, recordemos como en la Memoria de las reliquias que también compra se informa por escrito que se otorgan ochenta días de indulgencia a quien rece una oración vocal a la imagen impresa de Santiago.

31 FreedBerg, El poder de las imágenes..., págs. 141-159.

32 Antonio Bonet Correa, Fiesta, poder y arquitectura. Aproximaciones al Barroco español, Madrid, Akal, 1990, págs. 66-68. Véanse ejemplos en Maurizio FAgiolo dell'Arco, La festa barocca, Corpus delle feste a Roma, Roma, Edizioni de Lucca, 1997; en Marcello Fagiolo (cur.), La Festa a Roma. Dal Rinascimento al 1870, Roma, Umberto Allemandi \& C., 1997, 2 vols; y en el catálogo de imágenes de Víctor MíngueZ et al., La fiesta barroca: la corte del rey (1555-1808), Castelló de la Plana, Universitat Jaume I, 2016.
} 


\section{EL ALTAR MAYOR SEGÚN VARELA}

El "retrato" del altar mayor responde al interés de la época por producir estampas de imágenes de devoción, generalmente escultóricas, tal como se veneraban en sus altares y acompañadas de los muebles donde se exhibían, con sus atributos y accesorios ${ }^{33}$ (Fig. 4). Se busca representar la realidad y la tridimensionalidad para hacer sentir al espectador la presencia de las imágenes originales, en este caso las tres esculturas del apóstol Santiago, Patrón y Tutor de las Españas, dispuestas en el recinto donde se halla la tumba apostólica. Para ello Varela realizó el dibujo del altar en perspectiva desde un punto ubicado en el eje longitudinal de la basílica, en el área del crucero, a nivel del suelo, lo que permite una visión global frontal y de abajo arriba de toda la capilla mayor. En ella representa la misma máquina barroca que se observa en el grabado de 1717, captada desde un punto muy similar, siendo de hecho ambas imágenes muy parecidas (contrastar Figs. 4 y 7). Así, figura la mesa del altar; el camarín con la estatua medieval de Santiago in cathedra, el primero hito vertical que señala donde se halla soterrado el mausoleo apostólico y la segunda objeto del abrazo y beso de los peregrinos; el Santiago Peregrino y los cuatro reyes españoles arrodillados que le rodean y rinden homenaje; el baldaquino con el gigantesco Santiago Matamoros en su caballo atacando a cuatro sarracenos que huyen despavoridos; $y$, por fin, la pérgola de columnas salomónicas que reviste la arquitectura medieval de la basílica, la cual no aparece en la imagen. Se trata del aparato de presentación de las tres esculturas jacobeas construido por los maestros de obras catedralicios Francisco de Antas y Domingo de Andrade entre las décadas de 1650 y 1670, siguiendo al menos parcialmente una traza del arquitecto y ensamblador real Pedro de la Torre de $1658^{34}$, siendo canónigo fabriquero José de Vega y Verdugo ${ }^{35}$ (Fig. 10). No obstante, el grabado de Varela documenta

\footnotetext{
33 Juan Carrete Parrondo, Fernando Checa Cremades y Valeriano Bozal, El Grabado en España (siglos XV al XVIII), Madrid, Espasa Calpe, 1987 (Summa Artis. Historia general del arte, 31), págs. 233246 y 412-423; Javier Portús y Jesusa VEGA, La estampa religiosa en la España del Antiguo Régimen, Madrid, Fundación Universitaria Española, 1998; Antonio MORENO GARRIDO, La estampa de devoción en la España de los siglos XVIII y XIX: trescientos cincuenta y siete grabados, Granada, Universidad de Granada, 2015.

${ }^{34}$ ACS, IG 534, Libro $2^{\circ}$ de Fábrica, 1658, fol. 55v. .

35 Jesús CARro GARCíA, "Del Románico al Barroco: Vega y Verdugo y la capilla mayor de la Catedral de Santiago", Cuadernos de Estudios Gallegos, vol. 17, 52 (1962), págs. 223-250; Antonio BonET CoRREA, La arquitectura en Galicia durante el siglo XVII, Madrid, CSIC, 1984 (1. a ed. 1966), págs. 265 y ss.; Xosé Manuel García Iglesias, A Catedral de Santiago e o Barroco, Santiago, Colegio de Arquitectos de Galicia, 1990, págs. 59 y ss.; Andrés A. Rosende VALDÉs, “A mayor gloria del Señor Santiago: el baldaquino de la catedral compostelana”, Semata, vol. 7-8 (1996), págs. 485-534 [monográfico titulado Las religiones en la historia de Galicia, coordinado por Marco V. García Quintela]; Miguel Taín GuZMÁN, Domingo de Andrade, Maestro de Obras de la Catedral de Santiago (1639-1712), vol. 1, Sada, Ediciós do Castro, 1998, págs. 353-400; Alfredo Vigo Trasancos, “Transformación, Utopía y Redescubrimiento.
} 
interesantes cambios en el monumento, particularmente toda la platería añadida a la mesa del altar, a la imagen sedente del Apóstol y al camarín, financiada por el arzobispo fray Antonio de Monroy $(1685-1715)^{36}$ para enriquecer el escenario jacobeo, siguiendo los nuevos postulados de la Iglesia de la Contrarreforma ${ }^{37}$. El propio prelado deja por escrito sus intenciones en un documento de 1701:

\begin{abstract}
...desde que nos allamos ocupando la silla arçovispal emos thenido siempre yntención y boluntad de que la capilla y altar mayor de dicha nuestra Santta y Aposttólica Yglessia hestubiesse con la deçencia y auttoridad que se requiere como Cassa Santta donde en los años de jubileo concurren de todo el mundo los fieles cristianos [y] para mayor honrra y gloria de nuestro Santo Apóstol y Patrón Señor Santiago ${ }^{38}$.
\end{abstract}

Sobre el actual dameado del pavimento realizado con jaspes y mármoles portugueses, negros y colorados, instalados entre 1671 y $1676^{39}$, se alza la plataforma sobre la que se dispone la mesa del altar, de similar cronología ${ }^{40}$, presidida

La Catedral desde el Barroco a nuestros días”, en Manuel Núñez Rodríguez (ed.), Santiago, la catedral y la memoria del arte, Santiago, Consorcio de Santiago, 2000, págs. 189-195; Miguel TAín GuZMÁN, "Los tres Santiagos de la capilla mayor de la Catedral de Santiago: iconografía, culto y ritos", en Paolo Caucci von Saucken (ed.), Visitandum est: santos y cultos en el Codex Calixtinus, actas del VII Congreso Internacional de Estudios Jacobeos (Santiago de Compostela, 16-19 de septiembre de 2004), Santiago de Compostela, Xunta de Galicia, 2005, págs. 277-303; Miguel TAín GuZMán, "El cenotafio del Apóstol de la Catedral de Santiago de Compostela. De los modelos romanos a los camarines castellanos y los sarcófagos reales de El Escorial”, Studi di Storia dell'Arte, 23 (2012), págs. 127-138; Simón VICENTE LÓPEZ, Vega y Verdugo, Peña de Toro y la introducción del barroco en Compostela, Santiago, Consorcio de Santiago; Teófilo Edicións, 2012, págs. 285-370.

${ }^{36}$ María Teresa Ríos Miramontes, Aportaciones al barroco gallego: un gran mecenazgo, Santiago de Compostela, M.T. Ríos, 1986, págs. 115-155; Miguel TAín GuZMÁn, "Monroy y la orfebrería del altar del Apóstol: el sentido de la magnificencia", en Francisco Singul (ed.), Platería y Azabachería en Santiago de Compostela. Objetos litúrgicos y devocionales para el rito sacro y la peregrinación (ss. $I X-X X)$, Santiago, Xunta de Galicia, 1998, págs. 253-302.

37 Jesús Rivas CARMONA, "El impacto de la Contrarreforma en las platerías catedralicias", Estudios de Platería. San Eloy 2003, Murcia, Universidad de Murcia, 2003, págs. 515-536.

38 Archivo Histórico Universitario de Santiago (en adelante AHUS), Protocolos de Santiago, Domingo Antonio Caamaño, leg. 3.037, 1701, Poder del cardenal don Francisco Verdugo que le dio el Ylustrísimo Reverendísimo Señor Arçovispo de Santiago, fol. 64r. ${ }^{\circ}$.

${ }^{39}$ Las piedras llegan en barcos de Portugal: ACS, IG 534, Libro $2^{\circ}$ de Fábrica, 1669-1670, fol. 212 v. ${ }^{\circ}$ y 1671, fol. 236v. ${ }^{\circ}$. Para trabajarlas se contrata en 1671 a varios especialistas por tres años: AHUS, Protocolos de Santiago, Antonio de Castro Jaspe, leg. S-1638, 29 de agosto de 1671, fols. 508r. ${ }^{\circ}-509 \mathrm{v} .^{\circ}$. En una carta de 1676 se afirma que no se necesitan alfombras porque con los jaspes no se ponen tantas como antes en la capilla mayor (ACS, IG 314, Indeterminado. Correspondencia 1675-1677, carta del capellán Manuel Suárez a Pedro de Argüelles del 2 de agosto). Más información en Miguel Taín GuZmán, "El viaje a Lisboa del canónigo fabriquero José de Vega y Verdugo (1669)", Quintana, 1 (2002), págs. 301311; ViCENTE LóPEZ, Vega y Verdugo..., págs. 194-199.

${ }^{40}$ Véanse las referencias documentales de la nota anterior y VICENTE LóPEZ, Vega y Verdugo..., págs. 224230; Miguel TAín GuZMán, "La antigua mesa del altar mayor de la Catedral de Santiago de Compostela: 
por la citada estatua de Santiago en cátedra exhibida al culto en el vano del camarín, destinada a presidir la celebración de la misa por el arzobispo o uno de los siete canónigos cardenales del cuerpo capitular ${ }^{41}$ (Fig. 5). A diferencia del grabado de 1717, donde aparecen representadas las arcadas de jaspes y mármoles de dicha mesa, hoy desaparecida, y el cenotafio apostólico que cobija en su interior, que aún se conserva bajo la actual (contrastar Figs. 4, 5 y 7), en la vista de Varela no se dibuja porque se oculta detrás de la cartela con la cita de Isaías y de un frontal decorado con roleos. Este último podría aludir bien a algún frontal textil catedralicio $^{42}$, bien al actual de plata, pero muy simplificado, realizado entre 1694 y 1695 por el platero Antonio de Montaos y que solo se exhibía en grandes festividades $^{43}$ (contrastar Figs. 4, 5 y 10). Encima se hallarían dispuestas las dos gradas de plata donadas por el arzobispo Monroy en 1697, con evidentes errores en la representación y sin dibujar a propósito los candeleros y la custodia para permitir una mejor visión de la imagen apostólica ${ }^{44}$ (contrastar Figs. 4, 5 y 10).

El mueble del camarín de madera contratado por Lucas Serrano y un joven Andrade en 1665, presenta en el grabado de Varela importantes cambios conforme a su aspecto en la representación de $1717^{45}$ (contrastar Figs. 4, 5 y 7). En efecto, sigue contando con su basamento marmóreo de apéndices avolutados y con el faldón metálico, hecho con la plata fundida procedente del baldaquino gótico precedente ${ }^{46}$, decorado ya con sus cenefas y macollas vegetales de metal dorado actuales que, comparadas con el adorno que figura en el grabado de Delgado, no queda claro sea el original ${ }^{47}$ (contrastar Figs. 4, 5 y 7). La alteración más importante consiste en la supresión del marco del vano donde se exhibe la estatua y de las cuatro dobles volutas que lo flanqueaban verticalmente, dos a cada lado, que luego se prolongaban en el citado faldón, como se observa en el grabado de 1717. Ello se debe a la instalación del frente metálico, el arco, la gloria y la cátedra actuales, los cuatro de plata, parte de ella dorada, encargados por

propuesta de reconstrucción”, Goya, 344 (2013), págs. 220-229; TAín GuZMÁN, "Il ritratto dell'altare maggiore...”, pág. 51.

${ }^{41}$ Richard A. Fletcher, A vida e o tempo de Diego Xelmírez, Vigo, Galaxia, 1993 (1. a ed. 1984), pág. 209.

${ }^{42}$ La colección de los frontales de la catedral se encuentra aún sin estudiar.

43 AHUS, Protocolos de Santiago, Tomás López de Quintáns, leg. S-1818, 1694, fols. 28r. ${ }^{\text {-2 } 29 r . ~}{ }^{\text {o; }}$ cfr. Ríos Miramontes, Aportaciones al barroco gallego..., págs. 121-124; TAín GuZMÁn, "Monroy y la orfebrería del altar del Apóstol..., págs. 254-257 y 287-288.

${ }^{4}$ ACS, leg. 487, Libro 44 de Actas Capitulares, 23 de diciembre de 1697, fol. 208v. ; cfr. Ríos MiRAMONTES, Aportaciones al barroco gallego..., págs. 124-125; TAín GUZMÁn, "Monroy y la orfebrería del altar del Apóstol...", págs. 257-258 y 293-294.

45 ACS, IG 718, Varia, doc. 479; cfr. TAín GuZmán, Domingo de Andrade..., vol. 1, págs. 364-367; TAín GuZMÁn, "El cenotafio del Apóstol...”, págs. 127-134; ViCEnTE LÓPEZ, Vega y Verdugo..., págs. 327-332. ${ }^{46}$ ACS, IG 534, Libro $2^{\circ}$ de Fábrica, 1669-1670, fol. 211v. ${ }^{\circ}$; 1671, fols. 235v ${ }^{\circ}, 236 \mathrm{v} .^{\circ}, 237 v^{\circ}{ }^{\circ}$ y 245v. y 1676-1680, fol. 321 r. $^{\circ}$ v. ${ }^{\circ}$.

${ }^{47}$ ACS, IG 534, Libro $2^{\circ}$ de Fábrica, 1671, fol. 237r. ${ }^{\circ}$. 


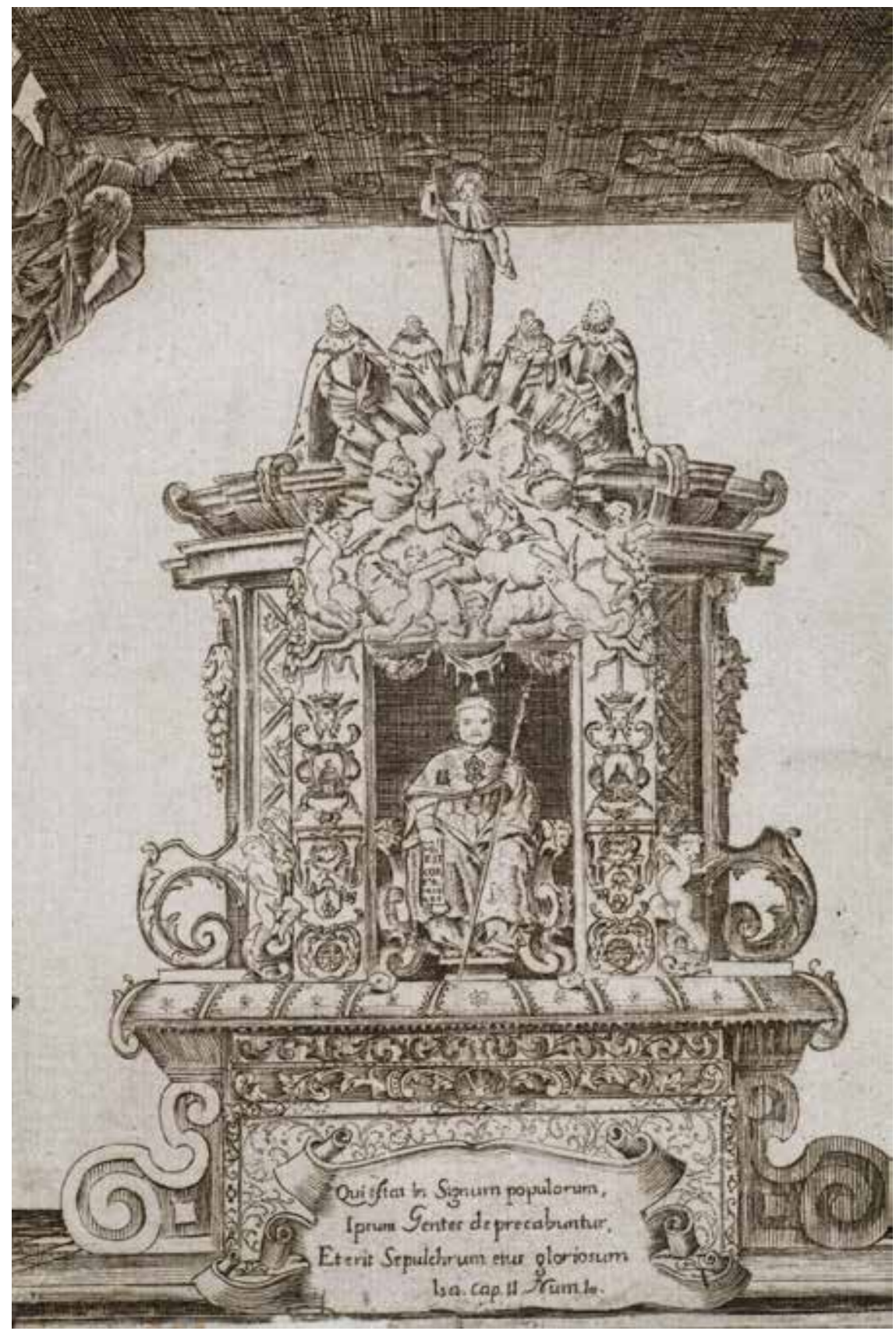

Fig. 5. Miguel Varela: detalle del altar y el camarín, grabado, 1723-1727; A.D. 24, J 2041-02; foto (C) Archives Départementales de la Dordogne. 
Monroy en 1701 para enaltecer la imagen jacobea, y muy bien representados en el trabajo de Varela ${ }^{48}$ (contrastar Figs. 4, 5 y 10). Tales elementos fueron ejecutados por el platero salmantino Juan de Figueroa y Vega y ya estaban instalados en la catedral en enero de 1704. El primero consiste en la lámina de plata que recubre toda la fachada del mueble, hoy lisa, pero que en el grabado aparece decorada con una gruesa línea en zigzag y motivos que parecen vegetales en su interior (contrastar Figs. 4, 5 y 10). Sobre ella, y enmarcando el hueco con la figura del Apóstol, se instala el arco de extradós mixtilíneo marcado con gruesa moldura y el intradós adintelado. Consta de sendas pilastras, sin capitel, con el fuste recorrido de arriba abajo por una cabeza de querubín alada y coronada; una orla con los bustos de sus discípulos Teodoro y Atanasio; una ménsula con placa dentada, tarjeta vegetal y sarta de frutas colgante; así como, para terminar, las armas del prelado. En la clave se dispone a Dios Padre bendiciendo a fieles y peregrinos con la mano derecha y asiendo el orbe con la izquierda, sobre un haz de rayos áureos y rodeado de una gloria de putti voladores y cabezas aladas en animado movimiento. Su instalación supuso la eliminación de la gigantesca cartela lígnea vegetal con la cabeza de un querubín mostrada en el grabado de 1717 (contrastar Figs. 4, 5, 7 y 10). El dintel del vano se decora con un cortinaje central, con pedrería engastada, y, en los flancos, sendas ricas guirnaldas florales. Dos juguetones angelotes se disponen de pie sobre sendas volutas laterales de rica hojarasca, buscan la mirada del espectador y, en el grabado, parecen portar asideros de lámparas votivas de aceite. La estatua apostólica se instala sobre una peana y dentro de un gigantesco trono, de exagerados brazos y pies avolutados, los primeros ornados con gruesos acantos y el cabezón de un querubín y los segundos con delfines, cuyo montaje, sospecho, hubo de suponer serrar el hueco para ampliar su anchura (contrastar Figs. 4, 5 y 7).

Más interesantes son los datos que aporta el grabado sobre la apariencia de la escultura de Santiago como padre fundador de la Iglesia, sentado en cátedra a la manera del apóstol San Pedro, concebida por el Maestro Mateo y que preside el altar desde $1211^{49}$ (Fig. 5). Me refiero a que documenta los cambios introducidos por Monroy al renovar sus atributos de peregrino. Como se sabe, ya se había modificado su iconografía inicial al vestirla Vega y Verdugo con una primera esclavina en 1672 -sustituida en 1693 por otra, obra del platero milanés José Clemente- $\mathrm{y}$ al hacerla asir su primer bordón con una mano nueva en

\footnotetext{
48 AHUS, Protocolos de Santiago, Domingo Antonio Caamaño, leg. S-2350, 1701, fols. 64r. ${ }^{\text {o- }} 68$ v. ${ }^{\text {; }}$; cfr. Ríos Miramontes, Aportaciones al barroco gallego..., págs. 142-145; TAín GuZMÁn, "Monroy y la orfebrería del altar del Apóstol...”, págs. 268-271.

${ }^{49}$ Manuel CAstiñeIras GonZÁLeZ, "El Maestro Mateo o la unidad de las artes”, en Pedro Luis Huerta Huerta (ed.), Maestros del románico en el Camino de Santiago, Aguilar de Campoo, Fundación Santa María La Real, 2010, págs. 206-210.
} 
1675, como se observa en la imagen de Delgado ${ }^{50}$ (Fig. 7). En cambio, en Varela se arropa ya con la actual esclavina, el bordón y la calabaza encargados por el prelado a Figueroa en $1704^{51}$ (contrastar Figs. 5 y 7). En el dibujo de la primera solo distinguimos el adorno central, con la cruz del Apóstol, y una concha sobre dos bordones cruzados, pero no el resto constituido por trofeos militares, otros motivos jacobeos y rica pedrería ${ }^{52}$. Igualmente, en el bastón no se distingue el adorno que recorre el fuste ni su remate esférico recubierto de diamantes, esmeraldas, rubíes y demás piedras, hoy desaparecido, pero que se conoce con cierto detalle gracias a la documentación y a que aparece representado en el cuadro de Juan Antonio García de Bouzas de $1748^{53}$ (contrastar Figs. 5 y 8). Lo mismo sucede con la calabaza, muy pequeña, apenas una esfera colgando del bordón en la imagen, perdida durante la ocupación francesa ${ }^{54}$, pero que se sabe se hallaba también cubierta de piedras preciosas, y que, como en el caso anterior, hoy se conoce gracias a la documentación y al óleo de García de Bouzas (contrastar Figs. 5 y 8). La túnica y el manto que viste el Apóstol parecen contar ya con la decoración estucada dorada actual o en todo caso ya están decorados, no figurando en el grabado de Delgado pero sí en la pintura de García de Bouzas (contrastar Figs. 4, 5, 7, 8 y 10). Por fin, con motivo de la reforma del vano, han desaparecido en Varela los dos querubines en vuelo que sostenían una corona sobre la cabeza apostólica, recuerdo de la ceremonia medieval de la coronatio $^{55}$ (contrastar Figs. 5 y 7).

Tales cambios no impiden continuar con los ritos jacobeos de los peregrinos que accedían al interior del camarín por sendas escaleras laterales, una de subida y la otra bajada, no dibujadas por Varela, accesibles como hoy por las estrechas puertas abiertas entre las arcadas del deambulatorio. Así, cuando se hallan dentro del mueble, en un recinto sugerido por la penumbra en el grabado, visten la estatua con la esclavina y el sombrero que han utilizado durante el viaje, así como la besan y abrazan repetidas veces en señal de aprecio, acciones que se llevaban a cabo por la espalda, las dos últimas todavía vigentes en nuestros

\footnotetext{
50 TAín GuZMÁn, “Los tres Santiagos...”, págs. 292-294; Vicente LóPEZ, Vega y Verdugo..., págs. 262263.

51 AHUS, Protocolos de Santiago, Domingo Antonio de Caamaño, leg. S-2350, 1704, fols. 4r. ${ }^{\circ}-9$ r. $^{\circ}$; cfr. Ríos Miramontes, Aportaciones al barroco gallego..., págs. 145-147; TAín GuZmán, "Monroy y la orfebrería del altar del Apóstol..., págs. 275-280 y 301-302; TAín GuZMÁn, "Los tres Santiagos...", págs. 294-297.

${ }^{52}$ La esclavina se expone hoy en el museo catedralicio, vistiendo la imagen una réplica.

53 Yzquierdo Peiró, Los tesoros de la Catedral..., págs. 231-232.

${ }^{54}$ Couselo Bouzas, Galicia artística en el siglo XVIII..., pág. 688.

55 Robert PlöTz, "Volviendo al tema: la coronatio", en Vicente Almazán (ed.), Padrón, Iria y las tradiciones jacobeas, Santiago, Xunta de Galicia; Xerencia de Promoción do Camiño de Santiago, 2004, págs. 101-122.
} 
EL ALTAR MAYOR DE LA CATEDRAL DE SANTIAGO EN TIEMPOS DEL ARZOBISPO HERRERO ESGUEVA (1723-1727)...

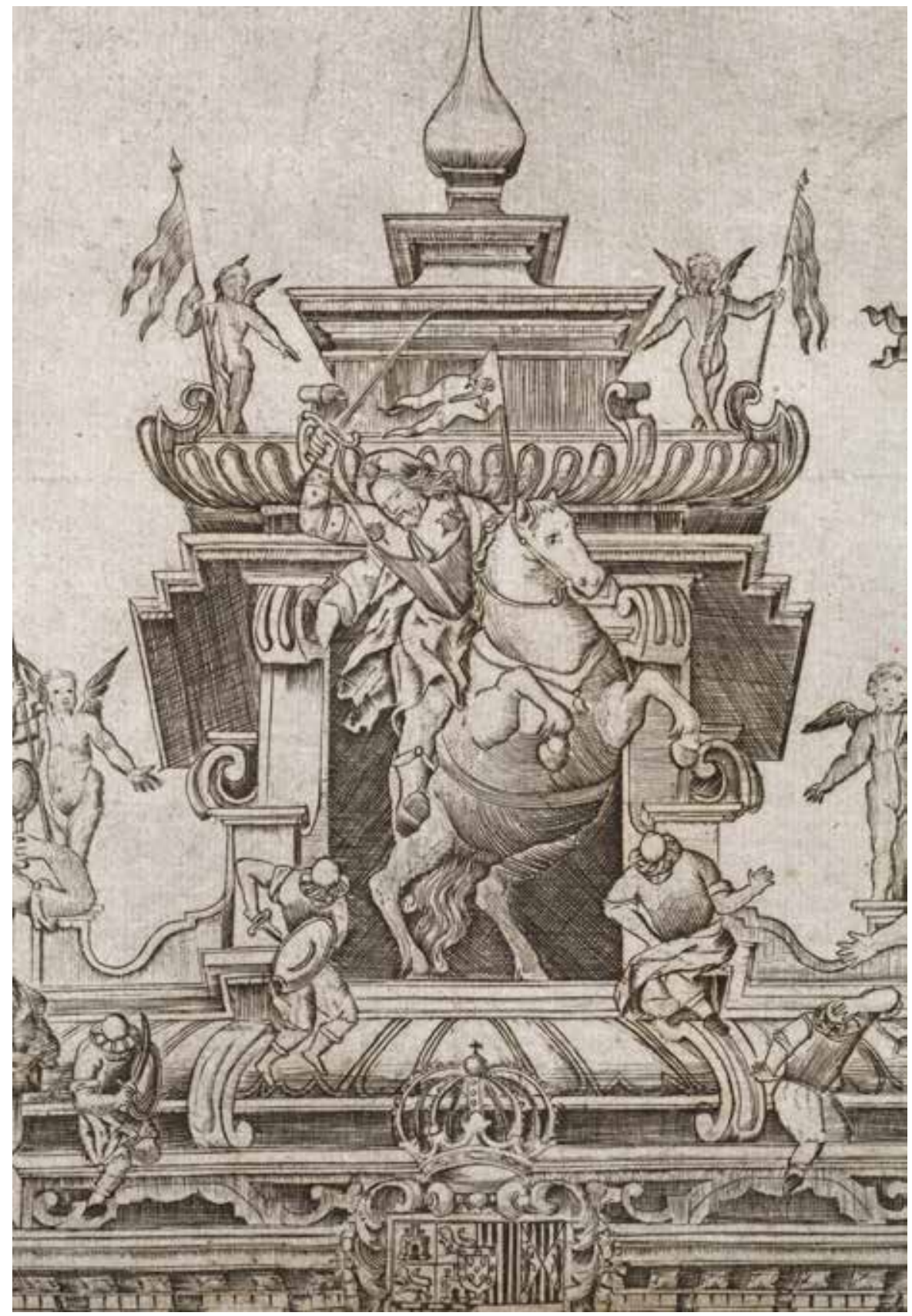

Fig. 6. Miguel Varela: detalle del Santiago Matamoros del baldaquino, grabado, 1723-1727; A.D. 24, J 2041-02; foto (C) Archives Départementales de la Dordogne. 
días $^{56}$. De ello da testimonio la literatura de viajes, como, por ejemplo, el relato de Albani de 1743:

Detrás de dicho altar mayor hay dos pequeñas puertecillas, es decir una del lado derecho y otra del lado izquierdo, que se abren solo dos horas por la mañana y dos al mediodía para hacer subir a los peregrinos a besar y a tocar la santa imagen de Santiago, que está encima del altar mayor, y no siendo peregrino no se puede subir; que cualquier persona acomodada, o caballero o dama o sacerdote u obispo, o incluso que sea el rey, no puede subir, si antes no se pone encima algún signo de peregrino, que este es privilegio solo de peregrinos, puesto por el Papa Calixto, y confirmado después por muchos otros pontífices; y por la puerta de la izquierda se sube ${ }^{57}$, y por la de la derecha se baja, y se suben doce peldaños y se bajan otros doce, y solo puede subir una persona a la vez porque es estrecha; al subir dicha escalera se encuentra un pequeño rellano que viene a estar justo detrás de la imagen de Santiago, y en dicho lugar hay siempre dos clérigos que enseñan cómo deben hacer los peregrinos; aunque más bien están para vigilar el tesoro y para dirigir a la gente; asi que, habiendo yo subido la primera vez, hice como hacían los demás, que se acostumbra a poner nuestro sombrero en la cabeza de la propia imagen del santo; habiendo hecho yo esta operación de poner mi sombrero en la cabeza, y tocarlo con el suyo propio, hice lo mismo con el bordón, con la muceta y la cartuchera, y revestí toda la indumentaria quitándola de encima del peregrino y poniéndola encima del santo apóstol Santiago, pero solo por un momento, que enseguida se quitan y se ponen de nuevo encima del peregrino, y luego se le da un abrazo a la santa imagen, encomendándome al santo según la intención; sali enseguida llevado por aquellos clérigos que son ayudantes y os hacen bajar por otra escalera a mano derecha para dejar espacio a los otros peregrinos que vienen cerca; y esta operación yo la hice al mediodía y por la mañana

\footnotetext{
56 Antón Pombo Rodríguez, "Ritos de los peregrinos en la Catedral de Santiago a través de los tiempos: del contacto con lo sagrado a la atracción por lo curioso", en José María Díaz Fernández y Ramón Yzquierdo Peiró (comiss.), Ceremonial, fiesta y liturgia en la Catedral de Santiago, Santiago, Consorcio de Santiago; Cabildo de la Catedral de Santiago, 2011, págs. 88-104.

${ }^{57}$ Se entiende que se trataría de la escalera izquierda si el peregrino se halla en el deambulatorio, después de asistir a su misa en la capilla del Rey de Francia.
} 
durante todo el tiempo que estuve aquí, porque me parecía que me diese una gran dignidad, que no es pequeño privilegio este que gozan los peregrinos ${ }^{58}$.

Encima del camarín aparecen cuatro reyes de España vestidos con armadura, capa y bengala, dispuestos de rodillas alrededor de un altarcillo con otra imagen de Santiago, esta vez vestido de peregrino (Figs. 4 y 5). En efecto, el Apóstol de pie, viste túnica sujeta en la cintura, esclavina y sombrero adornado con la concha jacobea, publicitando su condición de romero, mientras exhibe un libro en la mano izquierda en alusión a su labor evangelizadora. Se trata del actual grupo escultórico concertado en 1667 por Vega y Verdugo con el escultor berciano Pedro del Valle, que sigue la traza de Pedro de la Torre ${ }^{59}$. El Libro $2^{\circ}$ de Fábrica identifica a los monarcas a los que califica de vienhechores de esta Santa Iglesia: se trata de Alfonso II que la hiço, en referencia a que construyó la primera iglesia de Santiago para albergar en su interior la tumba apostólica, tras su "peregrinación" al enclave en la tercera década del siglo IX ${ }^{60}$. Ramiro I que conçedió el Votto a esta Santa Iglessia, es decir habría instaurado el Voto de Santiago, impuesto anual a pagar por el campesinado cristiano residente en la tierra conquistada a los reinos musulmanes de la península, principal fuente de ingresos de la corporación capitular durante siglos, un mérito que, en realidad, parece correspondería a Ramiro $\mathrm{II}^{61}$. Fernando V que ganó a Granada y le conçedió los Votos que llaman Viejos de Granada en referencia a que fue el conquistador, con su esposa Isabel, del reino nazarí de Granada y estableció el cobro del Voto en esas tierras, recibiendo el nombre de Voto Viejo de Granada, cuya renta se repartía a tercios entre el Hospital Real, el cabildo catedralicio y su capilla de

\footnotetext{
58 Albani, Viaje de Nápoles a Santiago..., pág. 221; transcripción original en italiano en pág. 89. Otros peregrinos como Vanti en 1717 (cfr. Buonafede VANTI, Viaggio occidentale a S. Giacomo di Galizia..., págs. 80, 81, 83, 84, 86, 87, 88, 89 y 91), Naia en 1718 (cfr. Pugliese, Viaje a Santiago..., pág. 243), Manier en 1726 (cfr. García Mercadal, Viajes de extranjeros..., vol. 3, pág. 361) o Bacci en 1764 (cfr. SCALIA RÖSSLER, "La Galizia...”, págs. 146, 148 y 152) describen el mismo ceremonial.

59 ACS, IG 713, Varia, doc. 19; cfr. TAín GuZMÁn, "Los tres Santiagos de la capilla mayor...", págs. 278-285; Vicente LóPeZ, Vega y Verdugo..., págs. 332-336; Miguel Taín GuZMÁn, "La monarquía y el Patrón de las Españas: imágenes del patrocinio regio y la ofrenda real al apóstol Santiago”, en Inmaculada Rodríguez Moya y Víctor Mínguez Cornelles (eds.), Visiones de un imperio en fiesta, Madrid, Fundación Carlos de Amberes, 2016, págs. 191-222.

${ }^{60}$ Fernando López AlsinA, La ciudad de Santiago de Compostela en la Alta Edad Media, Santiago, Ayuntamiento de Santiago de Compostela; Centro de Estudios Jacobeos; Museo Nacional de las Peregrinaciones, 1988 , págs. 112-118 y 127-145.

${ }^{61}$ La invención de la fundación del Voto por Ramiro I en agradecimiento por la Victoria de Clavijo correspondería al canónigo cardenal Pedro Marcio en el siglo XII; cfr. LóPEZ AlsinA, La ciudad de Santiago..., págs. 174-186. Sobre esta renta eclesiástica véase Ofelia Rey CASTELAO, La Historiografia del Voto de Santiago. Recopilación crítica de una polémica histórica, Santiago, Universidad de Santiago de Compostela, 1985; Ofelia Rey Castelao, El Voto de Santiago, claves de un conflicto, Santiago de Compostela, [s. n.], 1993.
} 


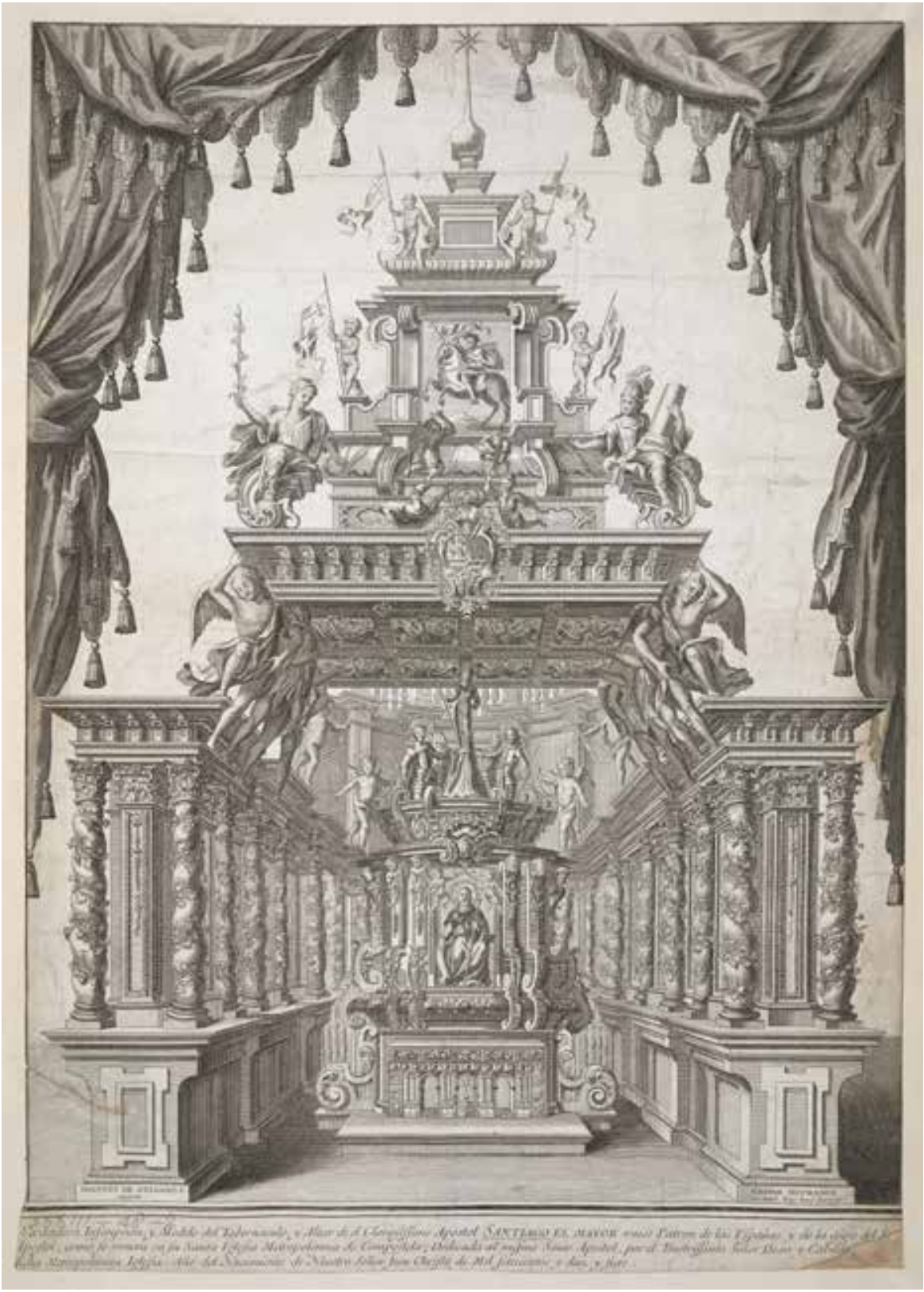

Fig. 7. Juan Delgado: el altar mayor de la catedral de Santiago de Compostela, grabado, 1717; British Library, Cartographic Items Maps K.Top.73.48.2; foto (C) The British Library Board. 
música $^{62}$. Y, finalmente, Felipe IV que dio y conçedió 1.000 escudos de oro en oro de juro y renta en cada un año para la Fábrica; y 40.000 ducados de vellón por una bes sobre las encomiendas de Santiago ${ }^{63}$; el tejo de oro y colgadura rica, con otras presseas, en alusión a sus ricos regalos, como una espectacular colección de colgaduras donada en 1655, y a la instauración de la Ofrenda Real el 25 de julio y de una renta anual para las obras patrocinadas por la Fábrica en el edificio catedralicio ${ }^{64}$. En efecto, el 9 de junio de 1643 había establecido la donación anual de 1.000 escudos de oro por los reinos de Castilla cada 25 de julio, día del martirio del Apóstol según el calendario romano, por la protección apostólica en el gobierno de sus reinos a él y a sus antecesores. Su presentación en nombre del rey correspondería bien al gobernador del Reino, bien al alcalde mayor más antiguo de la Real Audiencia de Galicia, y el dinero procedería del rendimiento de las rentas de millones del Reino gallego, no de las arcas reales. En la real cédula se declaran los motivos de la oferta pues indica que

\begin{abstract}
El Rey, por quanto deseando con humillde afecto, en reconocimiento de los beneficios que los señores reyes, nuestros antecessores, y yo y todos mis reinos hemos recibido mediante el patroçinio del glorioso apóstol señor Santiago, nuestro patrón, hacerle algún pequeño serbiçio y solicitar con él tenerle propiçio en nuestras necesidades y que nos asista en las presentes ocasiones para que con su ámparo, abivándose de nuestra parte la deboçión, consigamos entera seguridad en nuestra defenssa, resolví, entre otras cosas, que el Reyno, por bía de reconocimiento, embie cada año al santo mil escudos en oro... ${ }^{65}$.
\end{abstract}

\footnotetext{
${ }^{62}$ Ofelia Rey Castelao, "La fiscalidad jacobea en Andalucía (1492-1834)", en Juan Luis Castellano Castellano y Miguel Luis López-Guadalupe Muñoz (eds.), Homenaje a Don Antonio Domínguez Ortiz, vol. 1, Granada, Universidad de Granada, 2008, págs. 773-797.

632.000 ducados anuales durante veinte años.

${ }^{64}$ ACS, IG 534, Libro $2^{\circ}$ de Fábrica, 1669, fol. 223v..

${ }^{65}$ Véase copia de la cédula real en ACS, IG 360: Ofrendas, documento: Fábrica. Zédulas reales tocantes a los 1000 escudos de oro que la Magestad del rey $d$. Phelipe $4^{\circ}$ (que Dios guarde) manda se ofrezcan perpetuamente..., fols. $1 \mathrm{v} .^{\circ}-2 v^{\circ}$. Sobre la historia de la ofrenda véanse José María ZEPEDANO y CARNERO, Historia y descripción arqueológica de la Basílica Compostelana, Lugo, Soto Freire, 1870, págs. 131-140; Bernardo BARREIRo (dir.), "La Oferta de mil escudos hecha anualmente al Apóstol Santiago por los Reinos de León y Castilla”, Galicia Diplomática, vol. 2, núm. 3 (22 de julio de 1883), págs. 17-20; López Ferreiro, Historia de la Santa A. M. Iglesia de Santiago..., vol. 9, págs. 101-102; Pablo PÉrez Costanti, "Fiestas Compostelanas de 1643. La Ofrenda Nacional al Patrono de España", en Notas Viejas Galicianas, vol. 3, Vigo, Sindicatos Católicos, 1926, págs. 153-161; Ofelia Rey Castelao, "Las épocas moderna y contemporánea”, en Xosé Manuel García Iglesias (dir.), La Catedral de Santiago de Compostela, Laracha, Xuntanza Editorial, 1993 (Patrimonio Histórico I, Catedrales 1), págs. 69-75; José Antonio Tojo Ramallo, Fiestas del Apóstol 1500-1985. Una aproximación a la historia del ocio y el tiempo libre en la Ciudad de Santiago a través de sus fiestas patronales, Santiago, Consorcio de Santiago,
} 
Otro despacho de días después, el 17 de junio, confirma la ofrenda, concediendo además a la Fábrica catedralicia la cantidad de 2.000 ducados anuales sobre los frutos y rentas de la mitra compostelana durante veinte años, y otros 2.000 sobre las vacantes de las encomiendas de la Orden de Santiago durante el mismo tiempo, para la construcción de una reja y nuevo retablo al Apóstol con que parece se podrán hacer estas dos obras con el lucimiento y grandeza que se deve al Santo y correspondientes a mi afecto y devoçión, origen de la financiación de la construcción del mobiliario barroco representado en el grabado ${ }^{66}$. La pensión sobre las rentas de la mitra fue prorrogada durante años, no así las que gravaban las encomiendas, utilizándose ese dinero para la renovación barroca del edificio catedralicio ${ }^{67}$. La referencia en la documentación a la gratitud de la Corona por la tutela del Apóstol explica la presencia de los reyes más significativos en la historia de la iglesia compostelana en el conjunto escultórico catedralicio $^{68}$. También podría entenderse como una compensación de Felipe IV al agravio infringido a Santiago por su desafortunado apoyo a Santa Teresa de Jesús como copatrona de sus reinos ${ }^{69}$. Por consiguiente, los cuatro reyes han

1996, págs. 13-17; Concepción Presas Barrosa, Las Ofrendas Nacionales a Santiago Apóstol, Patrón de España (1949-2001), Santiago, Xunta de Galicia, 2002, págs. 19-75; y Ofelia Rey Castelao, Los mitos del Apóstol Santiago, Santiago; Gijón, Consorcio de Santiago; NigraTrea, 2006 (Libros da Brétema, 6) págs. 77-86.

${ }_{66}$ Véase la cédula real original en ACS, IG 360, Ofrendas, documento: Fábrica. Zédulas reales tocantes a los 1.000 escudos de oro que la Magestad del rey d. Phelipe $4^{\circ}$ (que Dios guarde) manda se ofrezcan perpetuamente..., fol. $6 \mathrm{r}^{\circ}{ }^{\mathrm{v}} .^{\mathbf{o}}$ y copia en ARCHIVo Histórico Diocesano DE SANTIAGo (en adelante AHDS), Fondo General, Festividades Religiosas, leg. 1, copia de la cédula. El texto del documento figura publicado en López Ferreiro, Historia de la Santa A. M. Iglesia de Santiago..., vol. 9, apénd. doc. 16, págs. 81-83.

${ }^{67}$ AHDS, Fondo General, Festividades Religiosas, leg. 1, Varios apuntes y noticias de las diligencias que se practicaron quando la concesión del señor D. Phelipe $4^{\circ}$ de las pensiones sobre encomiendas $y$ mitra y más oferta annae que hizo de mil escudos, año de 1740. Un libro de contabilidad recoge la entrada del dinero de la ofrenda entre 1643 y 1676: ACS, IG 360, Ofrendas, Libro de la entrada y salida de los 1.000 escudos de oro que en cada un año perpetuamente dotó a Nuestro Glorioso Apóstol y Patrón Único de las Hespañas Señor Santiago la Magestad del católico rey nuestro señor don Phelipe $4^{\circ}$ que Dios guarde. Començose la offerta de esta dotación año de 1643. Sobre la importancia del dinero de la ofrenda para el sostenimiento de la Fábrica y las obras emprendidas véase Ofelia REY CASTELAO, "La financiación de la fábrica catedralicia compostelana, siglos XVII-XIX”, Semata, vol. 22 (2010), págs. 311-328 [monográfico titulado El legado de las catedrales, coordinado por Roberto J. López y Miguel Taín Guzmán]. ${ }^{68}$ Sobre el origen y desarrollo del patronato en la Edad Media véase Klaus Herbers, Politica y veneración de santos en la Península Ibérica. Desarrollo del "Santiago Político", Pontevedra, Fundación Cultural Rutas del Románico, 1999. Sobre las vinculaciones de la Monarquía y el Apóstol en la Edad Moderna véase Víctor Nieto Alcaide (comis.), Santiago y la Monarquía de España (1504-1788), Madrid, Sociedad Estatal de Conmemoraciones Culturales, 2004.

${ }^{69}$ Ofelia Rey Castelao, “La disputa del patronazgo de la Monarquía: ¿Santiago o Santa Teresa?”, en José Martínez Millán y María Antonietta Visceglia (dirs.), La Monarquía de Felipe III: la Casa del Rey, vol. 1, Madrid, Fundación Mapfre, 2008, págs. 227-246; Erin Kathleen Rowe, Saint and Nation. Santiago, Teresa of Avila, and Plural Identities in Early Modern Spain, University Park, Pennsylvania State University, 2011; Ofelia Rey Castelao, “Teresa, Patrona de España”, Hispania Sacra, vol. 67 (2015), 


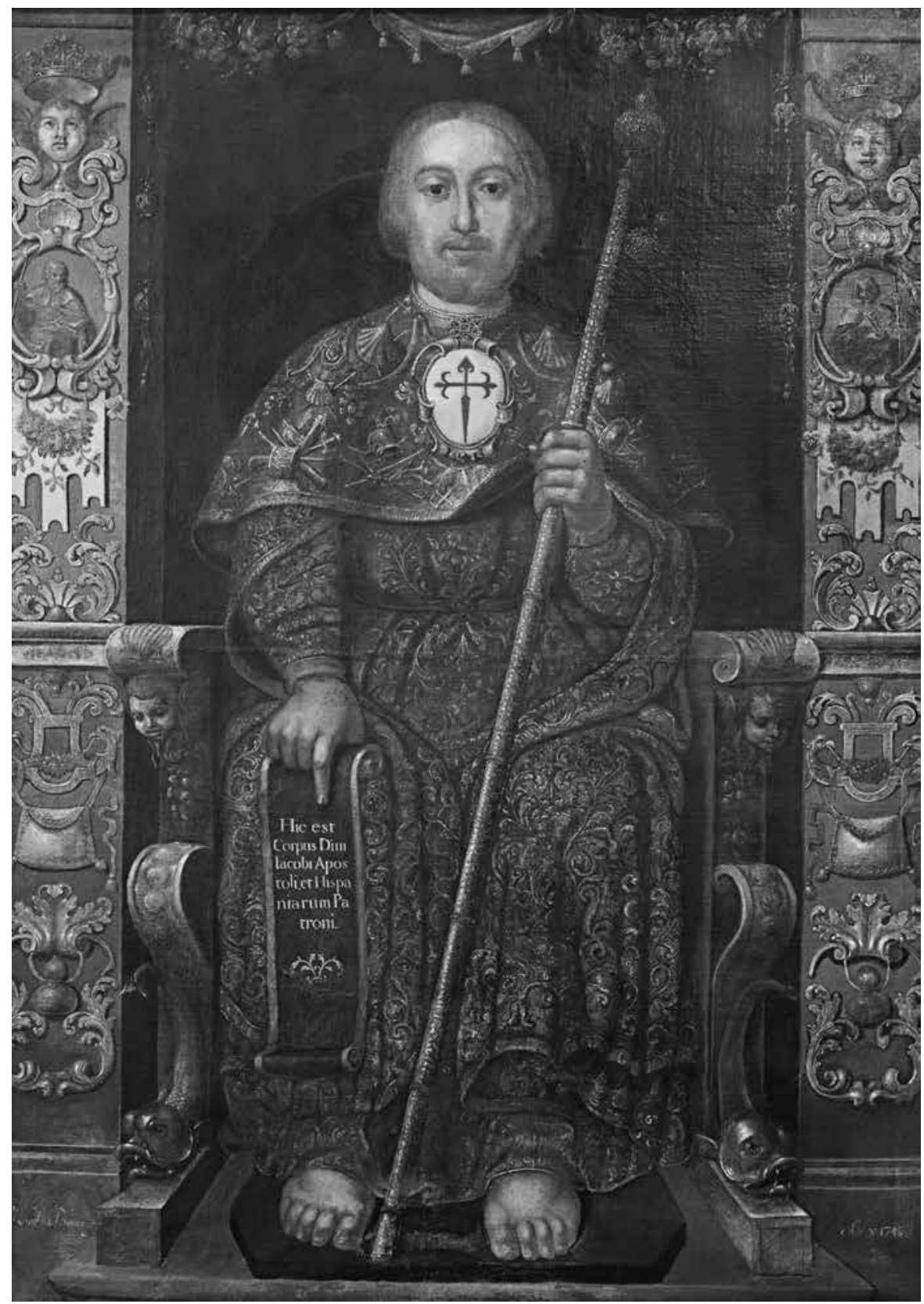

Fig. 8. Juan Antonio de García de Bouzas: la estatua del apóstol Santiago del altar mayor de la catedral de Santiago de Compostela, óleo sobre lienzo, 1748; Museo Catedral de Santiago (C) Fundación Catedral de Santiago; foto C. Martínez. 
sido elegidos para recordar la fundación real del santuario y sus privilegios, particularmente el cobro del Voto y la presentación de la Ofrenda. En el grupo actual solo se identifica con claridad el retrato de Felipe IV, ya fallecido cuando se firma el contrato, cuya cabeza hoy parece reubicada en su emplazamiento original. La poca definición de los rostros dibujados por Varela impide identificar con certeza dicho retrato, y documentar si entonces ya había tenido lugar el baile de cabezas reales que se ha propuesto recientemente ${ }^{70}$. No obstante, llama la atención que en el grabado el monarca delantero de la derecha luzca cuello de lechuguilla pues hoy solo la visten las imágenes traseras.

Tanto el camarín como el grupo escultórico real quedan guarnecidos debajo de un gigantesco baldaquino, sede de la escultura de un Santiago Caballero, cuya disposición remite a la tradición de los grandes catafalcos funerarios efímeros del barroco ${ }^{71}$ (Fig. 4). Varela dibuja las columnas salomónicas y el cielo artesonado en perspectiva desde el mismo punto bajo en que ha tomado las notas para representar el camarín. Su ubicación hace que su representación de los cuerpos superiores del mueble se "deformen" por la visión de abajo arriba y le impide representar detalles como los pies de los ángeles portadores de estandartes. No obstante, ello favorece la impresión realista y violenta del caballo apostólico dispuesto saltando apoyado sobre sus patas traseras y en acción de embestir a los enemigos de la cristiandad. Por otro lado, esta elección impide al autor captar el carácter bifrontal del mueble, faltando la figuración y el pináculo estrellado del remate del frente trasero, visible desde la capilla del trasaltar y desde los arcos en la curva del deambulatorio.

El grabado refleja con acierto como el baldaquino se inspira en el de Gian Lorenzo Bernini para el Vaticano, constituyendo eso sí una interpretación provincial, representando los pedestales marmóreos; las cuatro cajas de las columnas salomónicas que forran los cuatro machones medievales en los que se apoya; el cielo y la pirámide superior, de arquitectura calada; y parte de la figuración, al menos una parte ahuecada para evitar un peso excesivo ${ }^{72}$. Es decir, se abstiene de dibujar el forro lígneo de los pilares de la embocadura del presbiterio y de los posteriores ya en la capilla del trasaltar, así como el de la tribuna, con el afán de que el espectador pudiera centrar su atención en el mueble. Por consiguiente,

págs. 536-540.

70 TAín GuZMÁn, “La monarquía y el Patrón de las Españas...”, págs. 191-204.

${ }^{71}$ Rosende VALdÉs, “A mayor gloria del Señor Santiago...”, págs. 522-524. Contrástese el baldaquino compostelano con los catafalcos estudiados en Javier VARELA, La muerte del rey. El ceremonial funerario de la monarquía española (1500-1885), Madrid, Turner, 1990, págs. 112-116; Victoria Sото CABA, Los catafalcos reales del Barroco español: un estudio de la arquitectura efimera, Madrid, UNED, 1991, págs. 93-127; MíNGUEZ, La fiesta barroca..., págs. 101-109 y las imágenes de túmulos reales del catálogo. 72 Alfonso Rodríguez G. De Ceballos, "La huella de Bernini en España", [estudio introductorio] en Howard Hibbard, Bernini, Madrid, Xarait, 1982, pág. XII. 
primero se dispone el actual zócalo de mármoles y jaspes, de paneles morados y marcos negros, a juego con el pavimento, tenidos como de origen murciano, toledano y portugués ${ }^{73}$. Y luego, sobre él, las citadas cuatro cajas que esconden la arquitectura medieval y que se componen de cuatro pilastras en los ejes, de orden compuesto y fuste recorrido por una cinta, con lazos, sartas de frutas y remate borlado, así como de columnas salomónicas en los ángulos, de fuste recorrido por parras cargadas de racimos. Un entablamento muy bien dibujado une las dos cajas y se compone de un arquitrabe liso y un friso de triglifos adornados con tarjetas vegetales, ovas y gotas; metopas decoradas con roleos; y una volada cornisa sostenida por modillones ${ }^{74}$.

Sobre las cuatro cajas y en eje con las columnas entorchadas se disponen los ocho ángeles sostenedores del artefacto, siete tallados por Pedro del Valle y uno por Blas do Pereiro, según contrato de $1667^{75}$. Varela plasma verídicamente las posturas de los ocho, vestidos con túnicas y con las alas desplegadas en actitud de volar, si bien en ademán de posarse para colocar el baldaquino como dosel dignificador del recinto que alberga el sepulcro apostólico, recordando el proceder de los ángeles que trasladaron la Casa de la Virgen a Loreto. Los ocho apoyan la pirámide sobre el hombro de un brazo, los ángeles delanteros y penúltimos sobre el derecho, mientras que los efebos alados traseros y antepenúltimos lo hacen sobre el hombro contrario, mientras sostienen el entablamento con la mano de dicha extremidad. Los ángeles de frente y penúltimos miran hacia el presbiterio, como aparecen en el grabado, si bien los antepenúltimos y los traseros miran hacia la capilla del trasaltar, generándose dos espectaculares escorzos en los antepenúltimos apenas percibidos en la representación de Varela. Los ocho coinciden eso sí en apoyar un pie en la moldura saliente del arquitrabe y el otro sobre la cornisa.

El cielo que sostienen consiste en un deslumbrante artesonado inspirado en un grabado del Libro IV de Andrea Palladio, compuesto por doce casetones decorados con doce grandes rosetas en su interior y florones en las intersecciones de la cuadrícula ${ }^{76}$. Su entablamento es semejante al descrito para el revestimiento de los pilares, si bien aquí los modillones de la cornisa se decoran con hojas apergaminadas. En su centro se exhibe el escudo de la Casa Real, que no está

\footnotetext{
73 ACS, IG 534, Libro $2^{\circ}$ de Fábrica, 1669, fol. 222v.o; ACS, IG 599, Libro 34 de Actas Capitulares, 1669, fol. 356v. ; cfr. TAín GuZMÁn, "El viaje a Lisboa...”, págs. 306-307; y VicENTE LóPEZ, Vega y Verdugo..., págs. 341-364.

${ }^{74}$ El modelo de las columnas y su decoración data de 1662 (ACS, IG 534, Libro $2^{\circ}$ de Fábrica, 1662, fol. 104v. ${ }^{9}$ y su talla del año siguiente (ACS, IG 534, Libro $2^{\circ}$ de Fábrica, 1663, fol. 112v. ${ }^{\circ}$ ).

75 ACS, IG 713, Varia, doc. 19.

${ }^{76}$ Andrea Palladio, I quattro libri dell'architettura, Venetia, Dominico de' Franceschi, 1570, Libro IV, pág. 38 .
} 


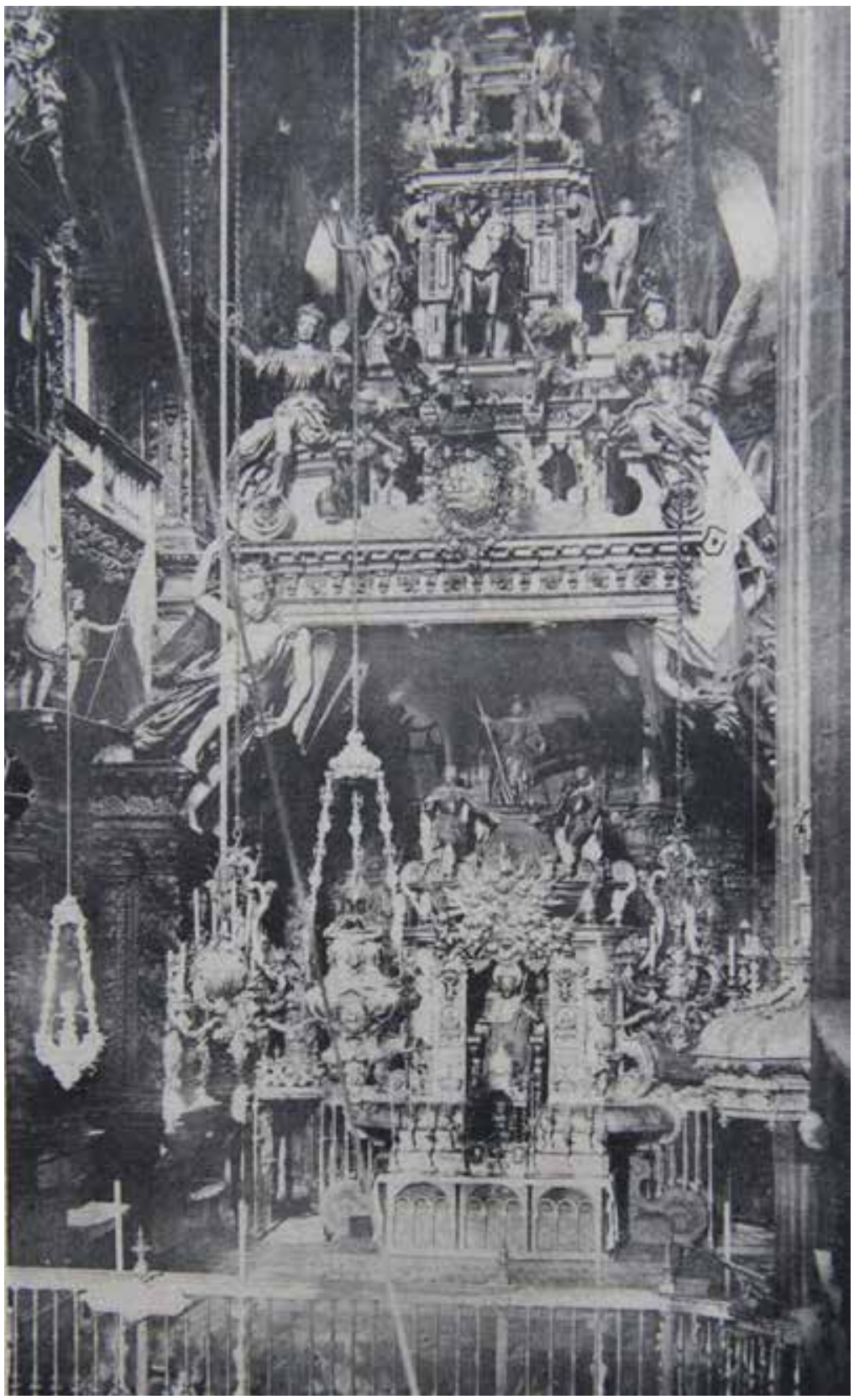

Fig. 9. El altar mayor de la catedral de Santiago de Compostela, todavía con los estandartes del Santiago Matamoros y los ángeles; foto de Hauser y Menet, núm. 2.058, anterior al año de 1905; foto colección Sanxiao-Lodeiro. 
claro si correspondería al tallado por el escultor Francisco de Brouces en $1672^{77}$. La duda se debe a que hay algunas diferencias entre el actual y los dibujados por Delgado y por Varela, pues, por ejemplo, en este último, falta la corona de laurel que lo guarnece y las armas de los cuatro cuarteles inferiores se disponen al revés (contrastar Figs. 4, 7 y 10). Su ubicación preferente y bien visible desde las naves y la sillería de coro capitular publicita otra vez el especial vínculo de la Corona con la Basílica del Patrón de las Españas, como ya se ha dicho de fundación real, y en agradecimiento por el Voto y la Ofrenda.

En el frente de la estructura, hacia el presbiterio, y encima del entablamento, se asientan dos gigantescas volutas, a modo de frontón partido, con la rosca inferior convertida en flor, obra del entallador Juan de Cabrera de $1668^{78}$. Sobre ellas se sientan dos de las virtudes cardinales de la fe cristiana. Me refiero a las imágenes de la Prudencia y la Fortaleza, no figurando en el grabado las otras dos por hallarse en la fachada trasera, las cuatro talladas por Pedro del Valle en $1667^{79}$. La primera se mira en un espejo que sostiene con la mano izquierda, mientras agarra tres serpientes en la derecha si bien la imagen actual solo muestra una. En cambio, la Fortaleza está fielmente representada y viste peto de armadura y casco y ase el fuste de una columna como símbolo de fuerza y sostén.

Sobre el dosel se levanta una complicada pirámide de dos pisos de tamaño decreciente, separados por una volada cornisa, bien dibujada por Varela. El primero consiste en un edículo que se apoya en un faldón, grapado con dos volutas, que recuerda al del camarín, y en un banco de carpintería calada que apenas se representa en el grabado. De su interior surge la escultura del Santiago ecuestre, recreando la legendaria Aparición de la Batalla de Clavijo, obra de Mateo de Prado de $1677^{80}$, milagro que convenía publicitar para justificar el cobro del Voto de Santiago, cuya base histórica se venía poniendo en duda sobre todo desde el siglo $\mathrm{XVI}^{81}$ (Figs. 4 y 6). En el grabado viste peto de armadura de caballero sobre la túnica y una capa agitadas por la violencia del ataque y el embiste del caballo, junto con una esclavina de peregrino adornada con conchas sobre bordones cruzados en aspa y un sombrero de ala ancha para proteger los ojos de la lluvia y el sol en los caminos, ornamentada con el mismo motivo. Sin embargo, la imagen actual viste una armadura completa y una capa estofada enganchada en el cuello cuyos pliegues delanteros debió de confundir Varela con una esclavina. Sí porta el sombrero de la representación, pero hoy la concha dispone los bordones verticalmente a ambos flancos y no en aspa como aparecen en el grabado y era lo

\footnotetext{
77 Talló otro para el frente trasero hoy perdido; ACS, IG 534, Libro $2^{\circ}$ de Fábrica, 1672, fol. 278r. ${ }^{\circ}$.

78 ACS, IG 534, Libro $2^{\circ}$ de Fábrica, 1668, fol. 204v. .

79 ACS, IG 713, Varia, doc. 19.

80 ACS, IG 534, Libro $2^{\circ}$ de Fábrica, 1677, fol. 344r. ${ }^{\circ}$.

${ }^{81}$ Rey Castelao, El Voto de Santiago, claves de un conflicto..., págs. 57 y ss.
} 
habitual. Con la mano izquierda coge el asta del estandarte con la cruz jacobea, de tela blanca según Guillaume Manier que visita Compostela en $1726^{82}$, hoy conocido por viejas fotografías (contrastar Figs. 6 y 9), y, es de suponer, las bridas para controlar la montura. En cambio, con el brazo derecho enarbola en alto una espada de filo recto, aunque la actual es de corte flamígero. Tal disposición concuerda con la iconografía tradicional del tema y las descripciones en la literatura apologética jacobea. Un ejemplo ilustrativo lo encontramos en el conocido libro de Mauro Castellá Ferrer según el cual el Patrón, Protector y Capitán General de las Españas apareció en el campo de batalla

armado de resplandecientes y blancas armas en un grande y hermoso cavallo blanco. En la mano derecha traya una espada desnuda y en la yzquierda un estandarte blanco... con una cruz colo$\operatorname{rada}^{83}$.

El caballo embravecido irrumpe de repente en la catedral y se lanza al vacío del presbiterio en persecución del enemigo, alzando sus poderosas patas delanteras en dirección izquierda, mientras el jinete se inclina hacia la derecha para arremeter con la espada al adversario, un juego de acciones que plasma la violencia de la acción y transmite una gran carga emotiva. Ataca a cuatro soldados infieles, obra del mismo escultor, que le dan la espalda y huyen aterrorizados hacia el precipicio ${ }^{84}$. Los más próximos al Apóstol presentan un mayor tamaño que los otros dos más alejados para jugar con el efecto de la profundidad y aumentar el volumen de la figura ecuestre apostólica al ser vistos desde abajo por los peregrinos. Los cuatro visten turbantes musulmanes, el primero de la izquierda más próximo al corcel se protege con una espada y un escudo con la media luna y el segundo, siempre a la izquierda, se defiende también con un alfanje, no contando la imagen actual con la rodela del grabado. Los otros dos, asimismo a la carrera, agitan sus brazos en gesto de espanto, si bien en la obra actual cuentan con espadas. Varela no ha dibujado la corona en la cabeza del moro de la izquierda más próximo al caballo que permitiría identificarlo con Abderramán II, emir de Córdoba, vencido en Clavijo.

El segundo piso dibujado repite la misma fórmula del anterior y también consiste en un edículo que sirve de peana a un gigantesco pináculo rematado en el cenit por una enorme estrella, recreando bajo las bóvedas de la basílica el milagro de la luminaria que, según la tradición, permitió al ermitaño Pelagio

\footnotetext{
${ }^{82}$ García Mercadal, Viajes de extranjeros..., vol. 3, pág. 361.

${ }^{83}$ Mauro Castellá Ferrer, Historia del Apostol de Iesus Christo Sanctiago Zebedeo Patron y Capitan General de las Españas, Madrid, Alonso Martin de Balboa, 1610, fols. 261v. ${ }^{\circ}-266$ r. $^{\circ}$.

${ }^{84}$ ACS, IG 534, Libro $2^{\circ}$ de Fábrica, 1677, fol. 344r. ${ }^{\circ}$.
} 


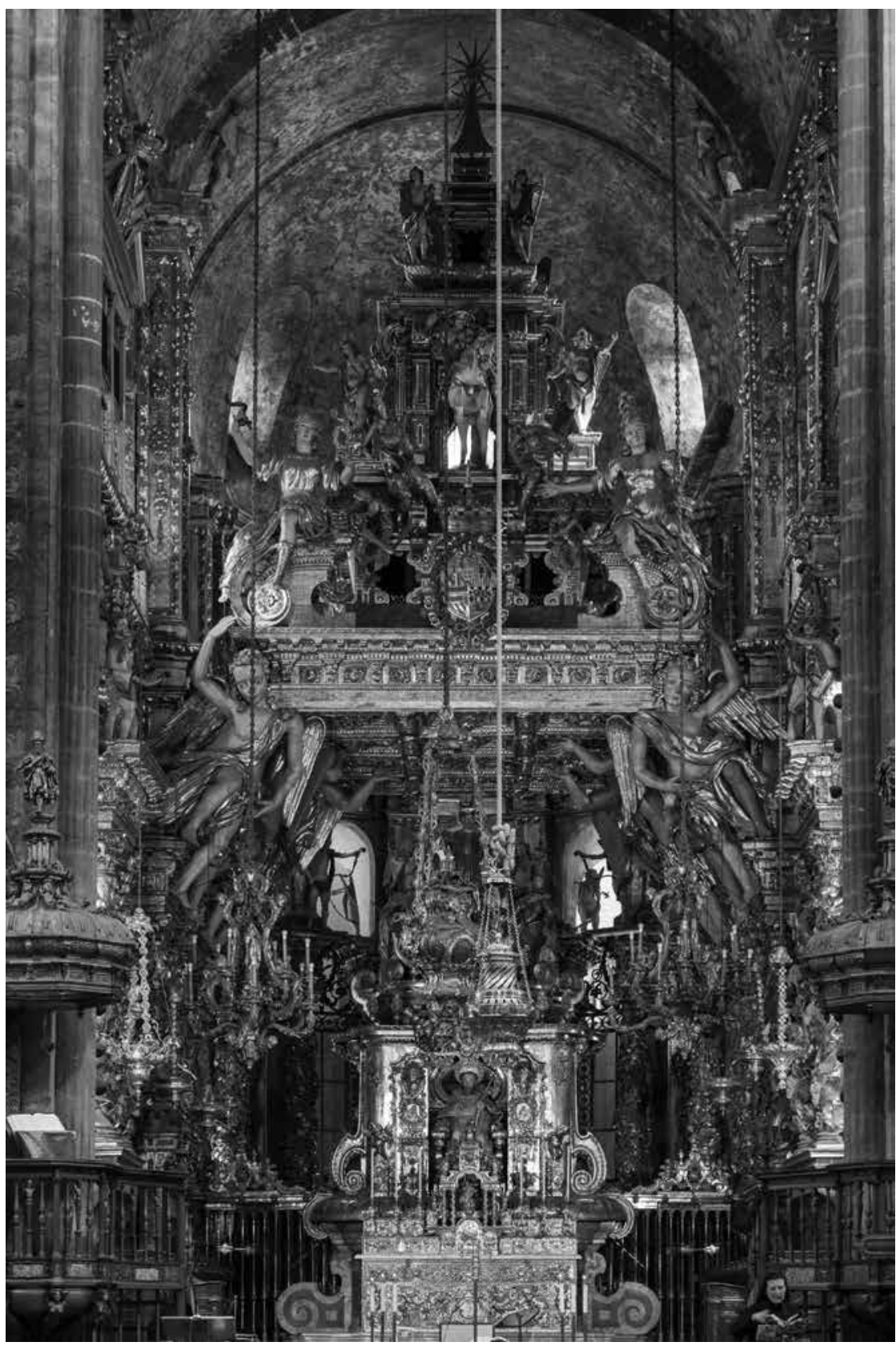

Fig. 10. El altar mayor de la catedral de Santiago de Compostela hoy; (C) Fundación Catedral de Santiago; foto Ovidio Aldegunde. 
descubrir la tumba del Apóstol hacia el año 813 (Fig. 4). En los grabados de Delgado y Varela el edículo se asienta sobre un faldón gallonado, otra vez grapado con volutas, y consiste en una urna cerrada en alusión al mausoleo jacobeo con la estrella de la inventio encima, una disposición que coincide con las armas del cuerpo capitular y que recuerda a los fieles y peregrinos que el apóstol Santiago se halla enterrado debajo del mueble ${ }^{85}$ (contrastar Figs. 4 y 7). Hoy, en cambio, la arquitectura es una caja abierta con un vano mixtilíneo en sus cuatro ejes sobre un faldón decorado con grandes hojas de acanto (contrastar Figs. 4, 6, 7 y 10). También el cuerpo celeste es distinto pues en Delgado y Varela tiene ocho rayos, uno de ellos apoyado en el vértice del pináculo, y el actual once, con terminaciones en astros más pequeños, y gravita directamente en el soporte (contrastar Figs. 4, 7 y 10). Esta falta de concordancia plantea la posibilidad de que el coronamiento vigente del baldaquino corresponda a alguna intervención de cronología posterior al grabado ${ }^{86}$.

Rodeando los dos edículos, se distribuyen diez ángeles, aunque en el grabado solo se dibujan los cuatro frontales (Fig. 4). Se cubren con sencillas túnicas y se disponen en actitud de marcha y asiendo lanzas que funcionan como astas de estandartes que, si fueran los mismos que los del grabado de 1717, presentarían la cruz del Apóstol (contrastar Figs. 4 y 7). Los angelotes del grabado de Delgado están desnudos y alígeros, mientras que los del de Varela son alados y visten túnicas que cubren parcialmente su cuerpo, es decir como los actuales, quedando la duda de si en todos los casos se tratarían de las diez figuras talladas por Pedro del Valle ${ }^{87}$ (contrastar Figs. 4, 7 y 10). Nada se sabe de lo ocurrido con los estandartes representados. En viejas fotografías los ángeles siguen enarbolando sus lanzas y banderas, aprovechándose los ángeles lampadarios sitos sobre la cornisa del revestimiento del presbiterio para la exhibición de nuevos trofeos hoy también desaparecidos (Fig. 9). Gracias a Zepedano, se conoce el origen de al menos algunos de ellos, victorias militares de las armas de la Corona de los siglos XVIII y XIX enviadas a la catedral en testimonio de gratitud al Santo protector $^{88}$.

$$
* * *
$$

\footnotetext{
${ }^{85}$ Contrástese dicho remate del baldaquino con el grabado del escudo del cabildo publicado en CASTELLÁ FERrer, Historia del Apostol..., fol. 222v. ${ }^{\circ}$.

${ }^{86}$ Por ejemplo, la llevada a cabo entre 1764 y 1766 en que se repolicroma todo el aparato de la capilla mayor y se repujan sus oros, se restaura el camarín y se restituyen docenas de alas, brazos, manos y pies de la figuración; cfr. Couselo BouZAs, Galicia Artística en el siglo XVIII..., págs. 294-295; QuiJADA MorandeIRA, Las obras en la Catedral de Santiago..., págs. 41-43, 47-48 y 53.

87 ACS, IG 534, Libro $2^{\circ}$ de Fábrica, 1670, fol. 228r. ${ }^{\circ}$ y 1671, fols. 243v. ${ }^{\circ}-244$ r. $^{\circ}$.

88 ZePedano y CARnero, Historia y descripción..., pág. 92.
} 
El hecho de que Boret adquiriera el grabado compostelano durante su primera visita a la ciudad en 1749 implica que el mismo estaría a la venta y disponible durante bastantes años después de su primera impresión entre 1723 y 1727, o que incluso podría haber habido reestampaciones posteriores, según la demanda de los peregrinos que visitasen el santuario entonces renovado para potenciar el culto apostólico ${ }^{89}$. La pieza constituyó durante un tiempo el recuerdo del viaje que podrían adquirir los romeros pues, como afirma Albani, no hay un solo día que no lleguen treinta o cuarenta peregrinos por la devoción de dicho santo ${ }^{90}$. Coincide, además, con una nueva mentalidad europea en cuanto a las imágenes en las que se exigía precision con la realidad, gracias a la influencia de los pintores de vedute topográficas como Canaletto o Gaspar van Winttel. También a la nueva moda de los viajeros de coleccionar estampas de las ciudades, edificios y santuarios europeos que visitaban, para los que por ejemplo Giuseppe Vasi publicó diez volúmenes de vistas de Roma con el título Magnificenze di Roma (Roma: 1747-1761), el tercero dedicado a las basílicas e iglesias antiguas de la ciudad y el sexto a sus parroquias, y Piranesi sus Vedute di Roma (Roma: 17511778) ${ }^{91}$. Así, la capilla mayor compostelana se convierte en el único argumento de la narración de exaltación jacobea representada en el grabado de Varela, sin necesidad de añadir personajes o peregrinos. Las tres imágenes del apóstol Santiago como Sabio de la Fe, Peregrino y Soldado de Cristo constituyen las principales protagonistas.

\section{BIBLIOGRAFÍA}

Albani, Nicola, Viaje de Nápoles a Santiago de Galicia, transcripción y traducción por Isabel González, Madrid, Edilán; Consorcio de Santiago, 1993.

Barral Iglesias, Alejandro, "El museo y el tesoro”, en Xosé Manuel García Iglesias (dir.), Santiago de Compostela, Laracha, Xuntanza Editorial, 1993 (Patrimonio Histórico Gallego I, Ciudades 2), págs. 459-535.

Barral Iglesias, Alejandro, "Reliquias y relicarios en la archidiócesis de Santiago", en José Manuel García Iglesias (comis.), En olor de santidad. Relicarios de Galicia, Santiago de Compostela, Xunta de Galicia, 2004, págs. 311-319.

\footnotetext{
${ }^{89}$ German Ramallo Asensio, "La potenciación del culto a los santos locales en las catedrales españolas durante los siglos del Barroco", en Germán Ramallo Asensio (ed.), Las catedrales españolas. Del Barroco a los Historicismos, Murcia, Universidad de Murcia, 2003, págs. 643-671.

${ }^{90}$ Albani, Viaje de Nápoles a Santiago..., pág. 219; transcripción original en italiano en pág. 87.

91 Delfín RodríGuEz, "De arquitectura y ciudades pintadas. Metáforas del tiempo, del espacio y del viaje”, en Delfín Rodríguez y Mar Borobia (comiss.), Arquitecturas pintadas: del Renacimiento al siglo XVIII [exposición], Museo Thyssen-Bornemisza; Fundación Caja Madrid, 18 octubre 2011 - 22 enero 2012, Madrid, Fundación Colección Thyssen-Bornemisza y Fundación Caja Madrid, 2011, págs. $42-43$.
} 
Barreiro, Bernardo (dir.), "La Oferta de mil escudos hecha anualmente al Apóstol Santiago por los Reinos de León y Castilla", Galicia Diplomática, vol. 2, núm. 3 (22 de julio de 1883), págs. 17-20.

Barreiro Fernández, Xosé Ramón, "Impresores galegos: Ignacio Aguayo y Aldemunde (17541819)”, Grial, vol. 21, núm. 82 (out.-dec. 1983), págs. 410-422.

Barriocanal López, Yolanda, El grabado compostelano del siglo XVIII, A Coruña, Fundación Pedro Barrié de la Maza, 1996.

Bonet Correa, Antonio, La arquitectura en Galicia durante el siglo XVII, Madrid, CSIC, 1984 (1. ${ }^{\mathrm{a}}$ ed. 1966).

Bonet Correa, Antonio, Fiesta, poder y arquitectura. Aproximaciones al Barroco español, Madrid, Akal, 1990.

Buonafede Vanti, Gian Lorenzo, Viaggio occidentale a S. Giacomo di Galizia, Nostra Signora della Barca e Finis Terrae (1717-18), Guido Tamburlini (ed.), Trieste, Università di Trieste, 2004.

Cabano Vázquez, José Ignacio (comis.), Los reyes y Santiago. Exposición de Documentos Reales de la Catedral de Santiago de Compostela, Santiago, Xunta de Galicia, 1988.

Cabano Vázquez, José Ignacio (ed.), A imprenta en Galicia: Século XIX, Santiago de Compostela, Xunta de Galicia, 2002, 2 vols.

Carrete Parrondo, Juan, Checa Cremades, Fernando y Bozal, Valeriano, El Grabado en España (siglos XV al XVIII), Madrid, Espasa Calpe, 1987 (Summa Artis. Historia general del arte, 31).

Carro García, Jesús, "La imagen sedente del apóstol en la Catedral de Santiago", Cuadernos de Estudios Gallegos, 15 (1950), págs. 43-51.

Carro García, Jesús, "Del Románico al Barroco: Vega y Verdugo y la capilla mayor de la Catedral de Santiago", Cuadernos de Estudios Gallegos, vol. 17, 52 (1962), págs. 223-250.

Castellá Ferrer, Mauro, Historia del Apostol de Iesus Christo Sanctiago Zebedeo Patron y Capitan General de las Españas, Madrid, Alonso Martin de Balboa, 1610.

Castiñeiras González, Manuel, "El Maestro Mateo o la unidad de las artes", en Pedro Luis Huerta Huerta (ed.), Maestros del románico en el Camino de Santiago, Aguilar de Campoo, Fundación Santa María La Real, 2010, págs. 187-239.

Constituciones establecidas por el illustrísimo i reverendísimo Señor Don Francisco Blanco, arzobispo de Santiago, Santiago, Ignacio Aguayo, 1781 (reimpresión).

Cortés Arrese, Miguel, "Retrato de don Miguel Herrero y Esgueva, obispo de Osma", La Ciudad de Seis Pisos. Las Edades del Hombre, [catálogo de la exposición organizada por la Fundación Las Edades del Hombre en la catedral de El Burgo de Osma (Soria) en el año 1997], Valladolid, Fundación Las Edades del Hombre, 1997, págs. 350-351.

Couselo Bouzas, José, Galicia Artística en el siglo XVIII y primer tercio del siglo XIX, Compostela, Imprenta del Seminario, 1932.

Fagiolo, Marcello (cur.), La Festa a Roma. Dal Rinascimento al 1870, Roma, Umberto Allemandi \& C., 1997, 2 vols.

Fagiolo dell'Arco, Maurizio, La festa barocca, Corpus delle feste a Roma, Roma, Edizioni de Lucca, 1997.

Fletcher, Richard A., A vida e o tempo de Diego Xelmírez, Vigo, Galaxia, 1993 (1. a ed. 1984). 
Freedberg, David, El poder de las imágenes. Estudios sobre la historia y la teoría de la respuesta, Madrid, Cátedra, 1992.

Gai, Lucia, "Certificado de peregrinación a Santiago (Compostela)", en Serafín Moralejo (comis.), Santiago, Camino de Europa. Culto y Cultura en la Peregrinación a Compostela, Santiago: Fundación Caja Madrid, Xunta de Galicia y Arzobispado de Santiago de Compostela, 1993, pp. 353-354.

García Iglesias, Xosé Manuel, A Catedral de Santiago e o Barroco, Santiago, Colegio de Arquitectos de Galicia, 1990.

García Mercadal, José, Viajes de extranjeros por España y Portugal. Vol. 3: Siglo XVIII, Madrid, Aguilar, 1962.

González Lopo, Domingo Luis, "Los avatares de la peregrinación jacobea en el Renacimiento y el Barroco", en Miguel Romaní Martínez y María Ángeles Novoa Gómez (eds.), Homenaje a José García Oro, Santiago, Universidade de Santiago de Compostela, 2002, págs. 171-192.

González Polvillo, Antonio, Análisis y repertorio de los tratados y manuales para la confesión en el mundo hispánico (ss. XV-XVIII), Huelva, Universidad de Huelva, 2009.

Jacomet, Humbert, "L'image de la majesté de Saint Jacques en France et sa relation à Compostelle. Etude iconographique", Actas del Congreso de Estudios Xacobeos, Santiago, Xunta de Galicia, 1995, págs. 431-474.

López Alsina, Fernando, La ciudad de Santiago de Compostela en la Alta Edad Media, Santiago de Compostela, Ayuntamiento de Santiago de Compostela; Centro de Estudios Jacobeos; Museo Nacional de las Peregrinaciones, 1988.

López Ferreiro, Antonio, Historia de la Santa A.M. Iglesia de Santiago de Compostela, Santiago, Seminario Conciliar Central, vol. 6, 1903; vol. 7, 1905; vol. 8, 1906; vol. 9, 1908; y vol. 10, 1908 .

Mendoza de los Ríos, Pablo, Theatro moral y politico de la noble academia compostelana, Santiago, [s. n.], 1731.

Mínguez, Víctor et al., La fiesta barroca: la corte del rey (1555-1808), Castelló de la Plana, Universitat Jaume I, 2016.

Moreno Garrido, Antonio, La estampa de devoción en la España de los siglos XVIII y XIX: trescientos cincuenta y siete grabados, Granada: Universidad de Granada, 2015.

Murguía, Manuel, El arte en Santiago durante el siglo XVIII y noticia de los artistas que florecieron en dicha ciudad y centuria, Madrid, Ricardo Fe, 1884.

Nieto Alcaide, Víctor (comis.), Santiago y la Monarquía de España (1504-1788), Madrid, Sociedad Estatal de Conmemoraciones Culturales, 2004.

Odriozola, Antonio y Barreiro, Xosé Ramón, Historia de la imprenta en Galicia, La Coruña, Biblioteca Gallega, 1992.

Pazos, Manuel R., El Episcopado gallego a la luz de documentos romanos, Madrid, Instituto Jerónimo Zurita, 1946.

Pérez Costanti, Pablo, "Fiestas Compostelanas de 1643. La Ofrenda Nacional al Patrono de España”, en Notas Viejas Galicianas, vol. 3, Vigo, Sindicatos Católicos, 1926, págs. 153161. 
Plötz, Robert, "Santiago de Compostela en la literatura odepórica”, Santiago de Compostela: ciudad y peregrino, Actas del V Congreso Internacional de Estudios Xacobeos, Santiago, Xunta de Galicia, 2000, págs. 101-122.

Plötz, Robert, "Volviendo al tema: la coronatio", en Vicente Almazán (ed.), Padrón, Iria y las tradiciones jacobeas, Santiago, Xunta de Galicia; Xerencia de Promoción do Camiño de Santiago, 2004, págs. 101-122.

Po-Chia Hsia, Ronnie, El mundo de la renovación católica, 1540-1770, Madrid, Akal, 2010.

Pombo Rodríguez, Antón, "Ritos de los peregrinos en la Catedral de Santiago a través de los tiempos: del contacto con lo sagrado a la atracción por lo curioso", en José María Díaz Fernández y Ramón Yzquierdo Peiró (comiss.), Ceremonial, fiesta y liturgia en la Catedral de Santiago, Santiago, Consorcio de Santiago; Cabildo de la Catedral de Santiago, 2011, págs. 82-109.

Portús, Javier y Vega, Jesusa, La estampa religiosa en la España del Antiguo Régimen, Madrid: Fundación Universitaria Española, 1998.

Presas Barrosa, Concepción, Las Ofrendas Nacionales a Santiago Apóstol, Patrón de España (1949-2001), Santiago, Xunta de Galicia, 2002.

Pugliese, Carmen, Viaje a Santiago de Compostela di Giacomo Antonio Naia (1717-1719), Pomigliano d'Arco, Edizioni Compostellane, 2012.

Quijada Morandeira, Benedicto José, Las obras en la Catedral de Santiago desde 1751 a 1800. Aportación documental, A Coruña, Diputación Provincial, 1997.

Ramallo Asensio, Germán, "La potenciación del culto a los santos locales en las catedrales españolas durante los siglos del Barroco", en Germán Ramallo Asensio (ed.), Las catedrales españolas. Del Barroco a los Historicismos, Murcia, Universidad de Murcia, 2003, págs. 643-671.

Reviriego, Bernard, "Sur les traces des pèlerins", Mémoire de la Dordogne, Revue des Archives Departementales, núm. 3 (1993), págs. 11-12.

Rey Castelao, Ofelia, La Historiografía del Voto de Santiago. Recopilación crítica de una polémica histórica, Santiago, Universidad de Santiago de Compostela, 1985.

Rey Castelao, Ofelia, El Voto de Santiago, claves de un conflicto, Santiago de Compostela, s.n., 1993.

Rey Castelao, Ofelia, "Las épocas moderna y contemporánea”, en Xosé Manuel García Iglesias (dir.), La Catedral de Santiago de Compostela, Laracha, Xuntanza Editorial, 1993 (Patrimonio Histórico I, Catedrales 1), págs. 69-75.

Rey Castelao, Ofelia, "La disputa del patronazgo de la Monarquía: ¿Santiago o Santa Teresa?", en José Martínez Millán y María Antonietta Visceglia (dirs.), La Monarquía de Felipe III: la Casa del Rey, vol. 1, Madrid, Fundación Mapfre, 2008, págs. 227-246.

Rey Castelao, Ofelia, Los mitos del Apóstol Santiago, Santiago; Gijón, Consorcio de Santiago; NigraTrea, 2006 (Libros da Brétema, 6).

Rey Castelao, Ofelia, "La disputa del patronazgo de la Monarquía: ¿Santiago o Santa Teresa?", en José Martínez Millán y María Antonietta Visceglia (dirs.), La Monarquía de Felipe III: la Casa del Rey, vol. 1, Madrid, Fundación Mapfre, 2008, págs. 227-246. 
Rey Castelao, Ofelia, "La fiscalidad jacobea en Andalucía (1492-1834)", en Juan Luis Castellano Castellano y Miguel Luis López-Guadalupe Muñoz (eds.), Homenaje a Don Antonio Domínguez Ortiz, vol. 1, Granada, Universidad de Granada, 2008, págs. 773-797.

Rey Castelao, Ofelia, "La financiación de la fábrica catedralicia compostelana, siglos XVIIXIX”, Semata, vol. 22 (2010), págs. 311-328 [monográfico titulado El legado de las catedrales, coordinado por Roberto J. López y Miguel Taín Guzmán].

Rey Castelao, Ofelia, “Teresa, Patrona de España”, Hispania Sacra, vol. 67 (2015), págs. 531-573.

Ríos Miramontes, María Teresa, Aportaciones al barroco gallego: un gran mecenazgo, Santiago de Compostela, M.T. Ríos, 1986.

Rivas Carmona, Jesús, "El impacto de la Contrarreforma en las platerías catedralicias", Estudios de Platería. San Eloy 2003, Murcia, Universidad de Murcia, 2003, págs. 515-536.

Rodríguez, Delfín, "De arquitectura y ciudades pintadas. Metáforas del tiempo, del espacio y del viaje", en Delfín Rodríguez y Mar Borobia (comiss.), Arquitecturas pintadas: del Renacimiento al siglo XVIII [exposición], Museo Thyssen-Bornemisza, Fundación Caja Madrid, 18 octubre 2011 - 22 enero 2012, Madrid, Fundación Colección Thyssen-Bornemisza y Fundación Caja Madrid, 2011, págs. 19-49.

Rodríguez G. de Ceballos, Alfonso, "La huella de Bernini en España", estudio introductorio en Howard Hibbard, Bernini, Madrid, Xarait, 1982, págs. VII-XXX.

Rosende Valdés, Andrés A., "A mayor gloria del Señor Santiago: el baldaquino de la catedral compostelana”, Semata, vol. 7-8 (1996), págs. 485-534 [monográfico titulado Las religiones en la historia de Galicia, coordinado por Marco V. García Quintela].

Rowe, Erin Kathleen, Saint and Nation. Santiago, Teresa of Avila, and Plural Identities in Early Modern Spain, University Park, Pennsylvania State University, 2011.

Scalia Rössler, Giovanna, "La Galizia nella relazione inédita di Paolo Bacci”, en Paolo G. Caucci von Saucken (ed.), I testi italiani del viaggio e pellegrinaggio a Santiago de Compostela e diorama sulla Galizia, Perugia, Università degli Studi di Perugia, 1983, págs. 111-160.

Soto Caba, Victoria, Los catafalcos reales del Barroco español: un estudio de la arquitectura efimera, Madrid, UNED, 1991.

Taín Guzmán, Miguel, Domingo de Andrade, Maestro de Obras de la Catedral de Santiago (1639-1712), Sada, Ediciós do Castro, 1998, 2 vols.

Taín Guzmán, Miguel, "Monroy y la orfebrería del altar del Apóstol: el sentido de la magnificencia", en Francisco Singul (ed.), Platería y Azabachería en Santiago de Compostela. Objetos litúrgicos y devocionales para el rito sacro y la peregrinación (ss. IX-XX), Santiago, Xunta de Galicia, 1998, págs. 253-302.

Taín Guzmán, Miguel, "El viaje a Lisboa del canónigo fabriquero José de Vega y Verdugo (1669)", Quintana, 1 (2002), págs. 301-311.

Taín Guzmán, Miguel, "Los tres Santiagos de la capilla mayor de la Catedral de Santiago: iconografía, culto y ritos", en Paolo Caucci von Saucken (ed.), Visitandum est: santos y cultos en el Codex Calixtinus, actas del VII Congreso Internacional de Estudios Jacobeos (Santiago de Compostela, 16-19 de septiembre de 2004), Santiago de Compostela, Xunta de Galicia, 2005, págs. 277-303. 
Taín Guzmán, Miguel, "El cenotafio del Apóstol de la Catedral de Santiago de Compostela. De los modelos romanos a los camarines castellanos y los sarcófagos reales de El Escorial”, Studi di Storia dell'Arte, 23 (2012), págs. 127-138.

Taín Guzmán, Miguel, "L’altare dell'Apostolo e i riti jacopei nella cattedrale di Santiago de Compostela. Alcune immagini tra XIV e XIX secolo", Compostella. Rivista del Centro Italiano di Studi Compostellani, 34 (2013), págs. 12-22.

Taín Guzmán, Miguel, "La antigua mesa del altar mayor de la Catedral de Santiago de Compostela: propuesta de reconstrucción”, Goya, 344 (2013), págs. 220-229.

Taín Guzmán, Miguel, "La monarquía y el Patrón de las Españas: imágenes del patrocinio regio y la ofrenda real al apóstol Santiago", en Inmaculada Rodríguez Moya y Víctor Mínguez Cornelles (eds.), Visiones de un imperio en fiesta, Madrid, Fundación Carlos de Amberes, 2016, págs. 191-222.

Taín Guzmán, Miguel, "Il ritratto dell'altare maggiore della cattedrale di Santiago de Compostela del pittore Juan Delgado (1717)", Compostella. Rivista del Centro Italiano di Studi Compostellani, 38 (2017), págs. 47-54.

Taín Guzmán, Miguel, La ciudad de Santiago de Compostela según los hermanos Juan y Pedro Fernández de Boán (ca. 1633-1646), Santiago, Teófilo Edicións y Consorcio de Santiago, 2019.

Thoenes, Christof, La fabbrica di San Pietro nelle incisioni dal Cinquecento all'Ottocento, Milan, Il Polifilo, 2000.

Tojo Ramallo, José Antonio, Fiestas del Apóstol 1500-1985. Una aproximación a la historia del ocio y el tiempo libre en la ciudad de Santiago a través de sus fiestas patronales, Santiago, Consorcio de Santiago, 1996.

Vanwijnsberghe, Dominique, "Réalité et fiction chez le maître du Livre d'Heures de Dresde. Le frontispiece du Cartulaire de 1'Hôpital Saint-Jacques de Tournai (Tournai, Bibliothèque de la Ville, Ms. 27)", Als ich can, Liber Amicorum in Memory of Professor Dr. Maurits Smeyers, Corpus of Illuminated Manuscripts, vol. 2, Leuven, Peeters, 2002, págs. 1509-1546.

Varela, Javier, La muerte del rey. El ceremonial funerario de la monarquía española (15001885), Madrid, Turner, 1990.

Vicente López, Simón, Vega y Verdugo, Peña de Toro y la introducción del barroco en Compostela, Santiago, Consorcio de Santiago; Teófilo Edicións, 2012.

Vigo Trasancos, Alfredo, "Transformación, Utopía y Redescubrimiento. La Catedral desde el Barroco a nuestros días", en Manuel Núñez Rodríguez (ed.), Santiago, la catedral y la memoria del arte, Santiago, Consorcio de Santiago, 2000, págs. 189-195.

Yzquierdo Peiró, Ramón, Los tesoros de la catedral de Santiago, Santiago de Compostela, Teófilo Edicións; Fundación Catedral de Santiago, 2018.

Zepedano y Carnero, José María, Historia y descripción arqueológica de la Basílica Compostelana, Lugo, Soto Freire, 1870. 